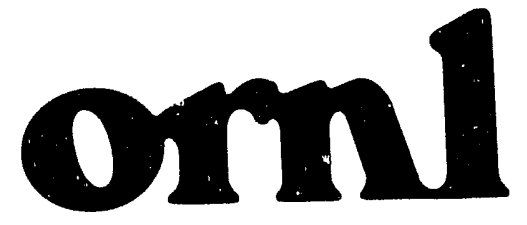

OAK RIDGE

NATIONAL

LABORATORY

MARTIN MARIETTA
ORNL/RAP-12/V3

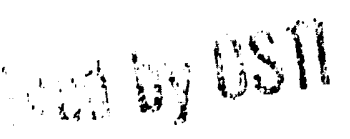

$\mid \angle B 101992$
RCRA Facilities Assessment (RFA) Oak Ridge National Laboratory Addendum August 25, 1987 
This report has been reproduced dircetty from the best avallable copy.

Available to DOE and DOE contractors trom the Office of Scientfic and Tecturt cal information, P.O. Box 62, Oak Ridpo, TN 37831; prices avaliablo from (615) 576-8401. FTS 626-8401.

Avellable to the public from the National Technical Information Service, U.S. Department of Commerce, 5285 Pont Royal Rd., Springtiold, VA 22161.

This report was prepared as an sccount of work sponsored by an egency of the United States Government. Neither the United States Government nor any agency thoreot, nor any of their employees, makes any warranty, expreas or implied, of sesumes any logal liability or responalbinty for the accuracy, com pletenses, or usofuinose of any information, apparatus, product, of process dieclosed, of represents that he use would not intringe prtvately owred rights. Rolerence herein 10 any epectic commercial product, process, or service by trade name, trademark, manutecturer, or otherwise, does not necossarily constit tuth or imply the endoreement, recommendation, or tavoring by the United States Governmemt or any egency thereot. The viows and opinions of authors expressed herein do not necessarily siate or reflect those of the Untted States Government or any agency thereot. 


\section{RCRA FACILITIES ASSESSMENT (RFA) OAK RIDGE NATIONAL LABORATORY Addendum August 25, 1987}

Date of Issue: August 1987

NÚCLEAR AND CHEMICAL WASTE PROGRAMS

(Activity No. KG 020000 0; ONLKG02)

Prepared by the

OAK RIDGE NATIONAL LABORATORY

Oak Ridge, Tennessee 37831

operated by

MARTIN MARIETTA ENERGY SYSTEMS, INC.

for the

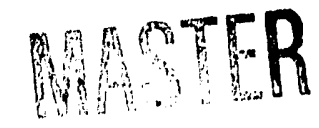

U.S. DEPARTMENT OF ENERGY

under Contract No. DE-AC05-84OR21400

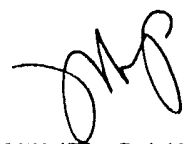

DISTAIBUTION C: 


\section{CONTENTS}

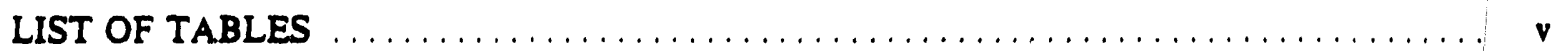

LIST OF FIGURES $\ldots \ldots \ldots \ldots \ldots \ldots \ldots \ldots \ldots \ldots \ldots \ldots \ldots \ldots \ldots \ldots \ldots \ldots \ldots$

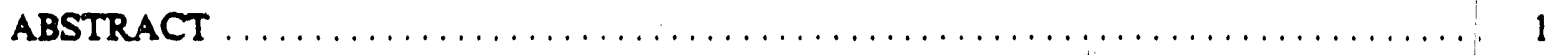

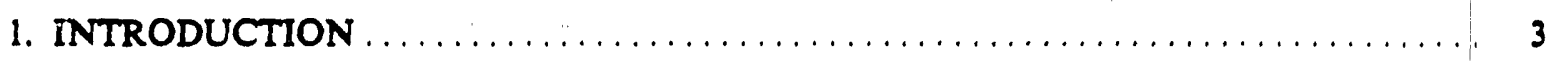

2. ADDITIONAL SOLID WASTE MANAGEMENT UNITS (SWMUs) $\ldots \ldots \ldots \ldots \ldots$

3. ADDITIONAL SAMPLING SURVEY DATA FOR SELECTED WAG $\ldots \ldots \ldots \ldots \ldots, 15$

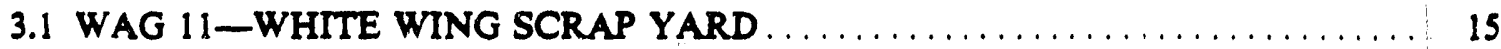

3.2 WAG 12 -CLOSED CONTRACTORS' LANDFILL $\ldots \ldots \ldots \ldots \ldots \ldots \ldots \ldots \ldots$

3.3 WAG 13-ENVIRONMENTAL RESEARCH AREAS $\ldots \ldots \ldots \ldots \ldots \ldots \ldots \ldots, 18$

3.4 WAG $15-$ ORNL FACILITIES AT THE Y-12 PLANT $\ldots \ldots \ldots \ldots \ldots \ldots \ldots, 22$

3.5 WAG 16-HEALTH PHYSICS RESEARCH REACTOR AREA .............. 23

3.6 WAG 19-HAZARDOUS WASTE TREATMENT AND STORAGE FACILITIES . 23

3.7 OTHER SITES-ABANDONED BURN PIT $\ldots \ldots \ldots \ldots \ldots \ldots \ldots \ldots \ldots \ldots$

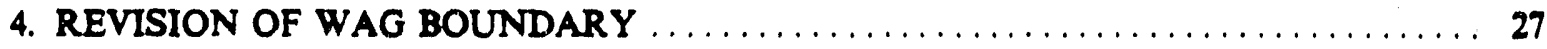

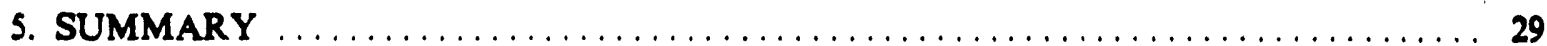

5.1 REGULATORY STATUS OF ADDITIONAL SWMUS AND SELECTED WAGs . . 29

$5.2 \mathrm{RI} / \mathrm{FS}$ SCHEDULE REVISIONS $\ldots \ldots \ldots \ldots \ldots \ldots \ldots \ldots \ldots \ldots \ldots$

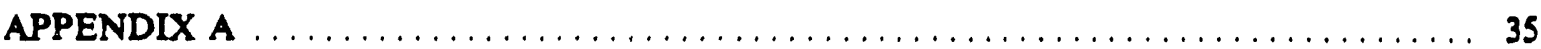

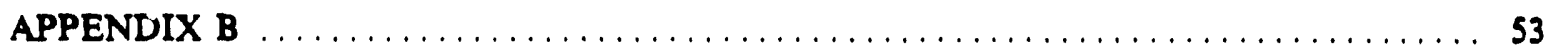




\section{LIST OF TABLES}

Table

Page No.

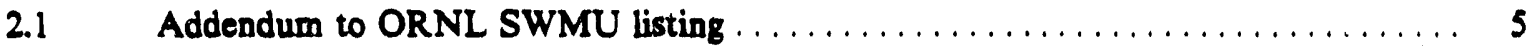

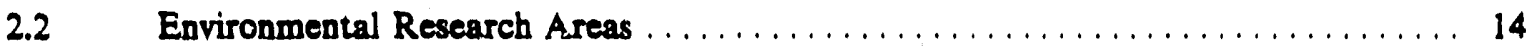

3.1 Survey results from WAG 11 in $1987 \ldots \ldots \ldots \ldots \ldots \ldots \ldots \ldots \ldots$ is

3.2 Survey results from piezometer wells at WAG $11 \ldots \ldots \ldots \ldots \ldots \ldots \ldots \ldots 17$

3.3 Survey results from piezometer wells at WAG $12 \ldots \ldots \ldots \ldots \ldots \ldots \ldots \ldots$

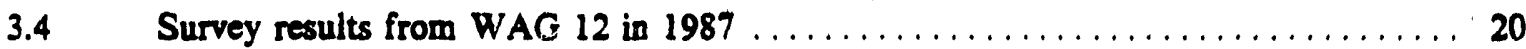

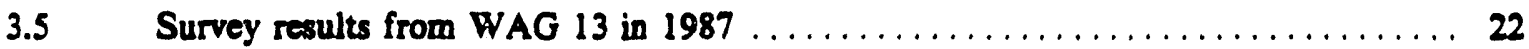

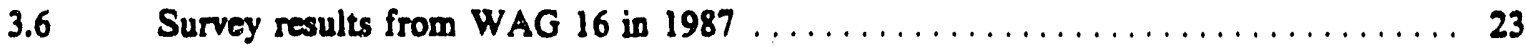

3.7 Survey results from Abandoned Burn Pit in $1987 \ldots \ldots \ldots \ldots \ldots \ldots \ldots \ldots$

4.1 Recommended actions for additional SWMUs . . . . . . . . . . . . . . . . . . . 29

4.2 Recommended actions for the WAGs $\ldots \ldots \ldots \ldots \ldots \ldots \ldots \ldots \ldots \ldots \ldots$

4.3 Preliminary schedules for ORNL Remedial Investigations/Feasibility Study . . . . 33

B.1 Recommended actions for the Environmental Research Areas ............... 56 


\section{LIST OF FIGURES}

Figure

Page No.

2.1 WAG 1-Main Plant Area, showing lorations of new SWMUs 1.55, 1.56a, and 1.56b

2.2 WAG 5-Solid Waste Disposal Area 5, showing locations of new SWMUs 5.11, 5.12, and 5.13.

2.3 WAG 7-LLW Pits and Trenches Area, showing locations of new SWMUs $7.4 d$ and 7.11

2.4 WAG 8-Melton Valley Area, showing location of new SWMI/ 8.11 ........ 10

2.5 WAG 16-Health Physics Research Reactor Area, showing location of new SWMUs $16.3,16.4$, and 16.5 and new sampling site

2.6 WAG 19-Hazardous Waste Treatment and Storage Facilities, showing location of new SWMUs 19.7 and 19.8

3.1 WAG 11-White Wing Scrap Yard, showing location of new sampling sites (stream and well samples)

3.2 WAG 12-Closed Contractors' Landfill, showing locations of new sampling sites ... 19

3.3 WAG 13-Environmental Research Areas, showing locations of new sampling sites . 21

3.4 OS-1-Abandoned Burn Pit, showing location of new sampling sites . . . . . . . 25

4.1 WAG 2-White Oak Creek/White Oak Lake .................... 28

B.1 Locations of Environmental Research Areas ........................ 57

B.2 Locations of Environmental Research Areas ...................... 58

B.3 Locations of Environmental Research Areas ........................ 59

B.4 Locations of Environmental Research Areas . . . . . . . . . . . . . . . . . . . . . 60 


\begin{abstract}
The Resource Conservation and Recovery Act (RCRA) Facilities Assessment (RFA) report identified approximately 250 Solid Waste Management Units (SWMUs) that were grouped into 20 Waste Area Groupings (WAGs).

Descriptions of SWMUs included location, type, size, dates of operation, type of waste handled, and evidence of releases. Analytical results from preliminary sampling studies around each of the WAGs served as the basis for recommendations concerning further actions, Remedial Investigations (R.Is), or deletion from any additional action under RCRA Section 3004(u). For several of the WAGs the evidence concerning the possible release of contaminants was inconclusive and additional sampling was recommended. Also a number of additional SWMUs and Environmental Research Areas (non-SWMUs) were listed but descriptive data were not submitted.

The purpose of this Addendum is to report the analytical data from additional sampling surveys of selected WAGs, to make recommendations concerning future remedial actions at these WAGs, and to provide descriptive information for additional SWMUs that were identified in the RFA.

Descriptions of additional SWMUs include summary sheets, selected sampling data, and recommendations for future RCRA Section 3004(u) remedial actions. Summary sheets for 34 Environmental Research Areas are included to maintain a comprehensive inventory of all ORNL potential remedial action sites.

Analytical results from additional sampling of selected WAGs are presented. Based on results from these previous sampling campaigns, recommendations conserning the necessity for RI Plans for all WAGs are included. This completes the RFA process for those SWMUs (excluding the container storage accumulation areas) listed in the HSWA RCRA permit for the ORNL Hazardous Waste Storage Facility, Building 7652.

Also included in this Addendum is a revised schedule for remedial investigations/feasibility studies (RI/FS).

This Addendum is a supplement to the RFA. Since information concerning the rationale for identifying releases, the sampling survey methodology, and the background information for each WAG is presented in the RFA, it is not repeated in the Addendum.
\end{abstract}




\section{INTRODUCTION}

The RCRA Facilities Assessment (RFA) report identified approximately 250 Solid Waste Management Units (SWMUs) that were grouped into 20 Waste Area Groupings (WAGs). Identification of each SWMU included information as to location, type, size, dates of operation, type of waste handled, and evidence of releases. Preliminary sampling studies were performed around each WAG to determir : if there was evidence of releases beyond its perimeter. Analytical results from the surveys and historical information were the basis for recommendations concerning further actions for each WAG. Remedial investigations (RIs) were recommended for WAGs 1-10 and 17; for WAGs 14,16,18, and 20, it was suggested that they be removed from further consideration for remedial action. For the remaining WAGs $(11,12,13,15$, and 19) the evidence concerning the possible release of contaminants was inconclusive and additional sampling was recommended. The purpose of this Addendum is to report the analytical data obtained from the additional surveys, to make recommendations concerning future remedial actions within these WAGs, and to provide descriptive information for additional sites listed in Table 1.2 of the RFA.

Since information concerning the rationale for identifying releases, the sampling survey methodology, and background information for each WAG is presented in the RFA, it is not repeated in this Addendum. 


\section{ADDITIONAL SOLID WASTE MANAGEMENT UNTTS (SWMUs)}

During the preparation of the original RFA, several additional SWMUs were discovered (see Table 2.1). No description of these additional sites was included in the RFA because there was insufficient time for an assessment of their potential for releases. Summary sheets for these newly identified sites are included in Appendix A.

Nine of the 17 SWMUs listed in Table 2.1 are septic tanks. There is no evidence that hazardous substances have been discharged into the tanks; therefore, it is recommended that they be

Talke 2.1 Addeaduen to ORNL SWMU linting

\begin{tabular}{|c|c|}
\hline SWMU No. & Description \\
\hline \multicolumn{2}{|l|}{ WAG 1} \\
\hline $\begin{array}{l}1.36 \\
1.55 \\
1.568, \mathrm{~b}\end{array}$ & $\begin{array}{l}\text { Inactive LLW Waste Collection Tank (WC-4) } \\
\text { Septic tank for Building } 5505 \text { ( } 5507) \\
\text { Inactive LIW waste collection tanks (W-19, W-20) } \\
\text { (formerly listed as part of the Metal } \\
\text { Recovery Facility) }\end{array}$ \\
\hline \multicolumn{2}{|l|}{ WAG 5} \\
\hline $\begin{array}{l}5.11 \\
5.12 \\
5.13\end{array}$ & $\begin{array}{l}\text { Septic tank (7831) } \\
\text { Septic tank }(7860) \\
\text { Septic tank (7853) }\end{array}$ \\
\hline \multicolumn{2}{|l|}{ WAG 7} \\
\hline $\begin{array}{l}7.4 d \\
7.11\end{array}$ & $\begin{array}{l}\text { Transfer line from Decontamination Facility to Pit } \\
\text { Septic tank (7819) }\end{array}$ \\
\hline \multicolumn{2}{|l|}{ WAG 9} \\
\hline 9.4 & Septic tank (7503) \\
\hline \multicolumn{2}{|l|}{ WAG 16} \\
\hline $\begin{array}{l}16.3 \\
16.4 \\
16.5\end{array}$ & $\begin{array}{l}\text { Buried scrap metal } \\
\text { Septic tank }(7709) \\
\text { Septic tank }(7710)\end{array}$ \\
\hline \multicolumn{2}{|l|}{ WAG 19} \\
\hline $\begin{array}{l}19.7 \\
19.8\end{array}$ & $\begin{array}{l}\text { Soil iajection of radioactive gas }(7659 \mathrm{c}) \\
\text { Explosive and shock-sensitive waste } \\
\text { detonation facility (7667) }\end{array}$ \\
\hline \multicolumn{2}{|l|}{ Other Sites } \\
\hline $\begin{array}{l}\text { OS.1 } \\
\text { OS.2 }\end{array}$ & $\begin{array}{l}\text { Abandoned burn pit near sanitary } \\
\text { waste compactor (0904) } \\
\text { Septic tank (0907) at Katy's Kitchen }\end{array}$ \\
\hline
\end{tabular}


deleted from consideration as potential sources of continuing release of hazardous constituents. As will be seen in later discussions, most of these tanks are located in WAGs that will require the preparation of an RI Plan.

Table 2.1 indicates that three additional SWMUs have been identified in WAG 1, and SWMU 1.36 is listed only for the purpose of indicating a change in operational status from active to inactive (no Summary Sheet is included in Appendix A, because the data in the RFA are still correct). SWMUs $1.56 \mathrm{a}$ and $1.56 \mathrm{~b}$ (inactive LL,W waste collection tanks W-19 and W-20) were originally included as a component of the non-SWMU remedial action site 1A.7 (Metal Recovery Facility) but have now been removed from that facility and identified as SWMUs. Finally, a septic tank (SWMU 1.55) has been identified and added to the list. The locations of these SWMUs are given in Fig. 2.1.

The number of SWMUs in WAG 5 has been increased to 13 by the addition of 3 septic tanks that were installed to provide sewage services to remote experimental facilities located in the WAG (Fig 2.2). The addition of these SWMU's does not alter the recommendation for WAG 5 that was presented in the RFA.

WAG 7 (LLW Pits and Trenches Area) has had twe SWMUs added: a septic tank (SWMU 7.11) and a leak site in a waste transfer line (SWMU 7.4d) (Fig. 2.3). The RFA indicated that an RI Plan will be required for WAG 7, and the addition of another leak site does not alter the initial recommendation.

An additional SWMU (SWMU 8.11) has been included in WAIS 8 (Melton Valley Area). Addition of this septic tank (see Fig. 2.4) does not alter the recommendation of the RFA to develop an R! Plan for WAG 8.

WAG 16 (Health Physics Research Reactor Area) has had three additional SWMUs identified. Two of these are septic tanks, and the third site is a buried scrap metal area (Fig. 2.5). Although the two septic tanks are not considered sources of hazardous waste discharge, the scrap metal area is a potential source. Since the RFA recommended eliminating WAG 16 from further 3004 (u) evaluations, additional sampling has been conducted at this WAG (see Sect. 3).

Two additional SWMUs have been added io WAG 19 (Hazardous Waste Treatment and Storage Facilities) (Fig. 2.6). Investigations conducted after these SWMUs were included in the RFA indicated that SW'MU 19.7 (Soil Injection of Radioactive Gas) was identified based on incorrect verbal information, and that no gas (radioactive or nonradioactive) was injected at the site. The experiment conducted was a thermal study performed for the high-level radioactive waste 


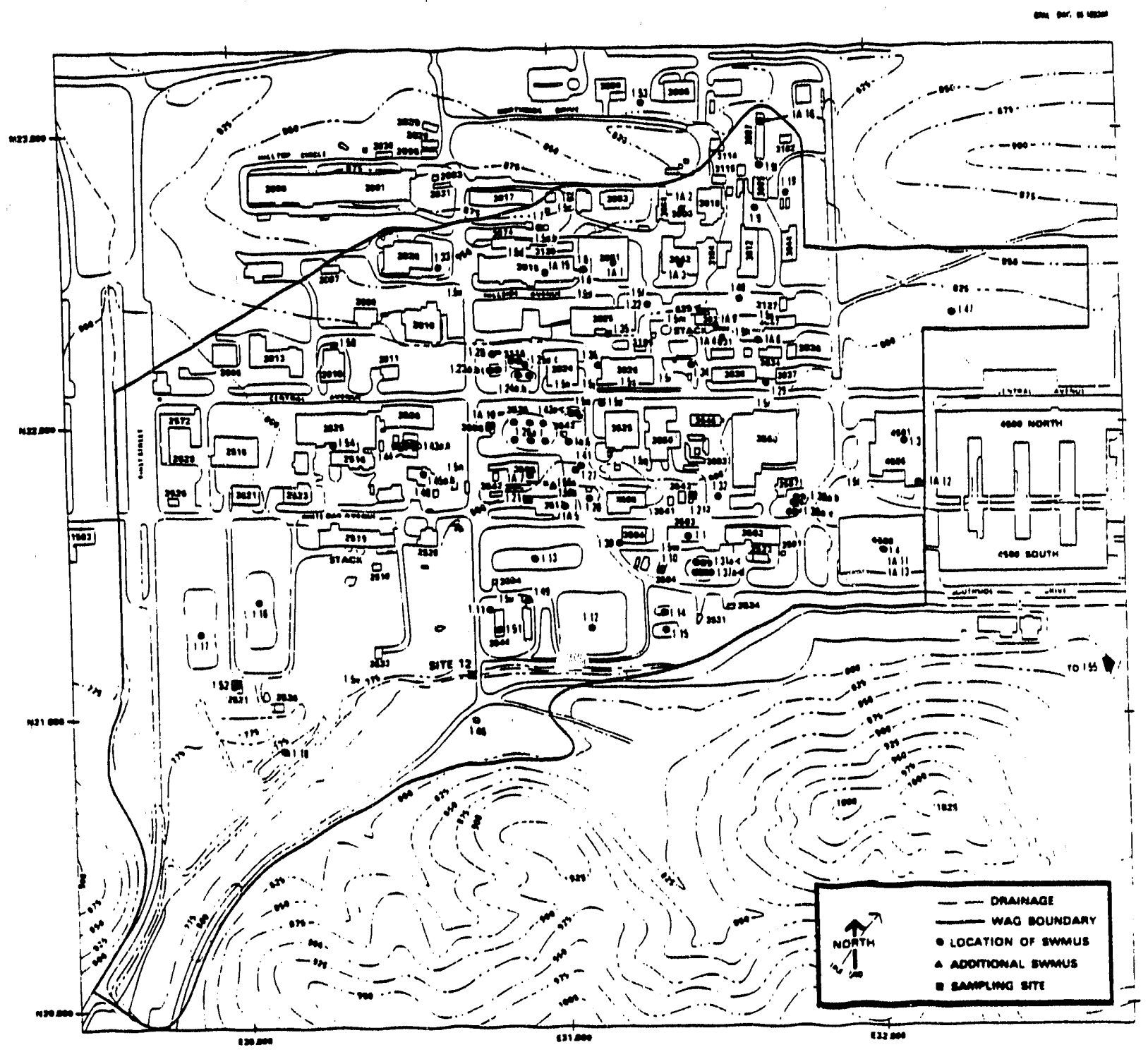

Fig. 2.1. WAG 1-Main Plant Arean showing location of additional SWMUs 1.55, 1.56an and 1.56b. 


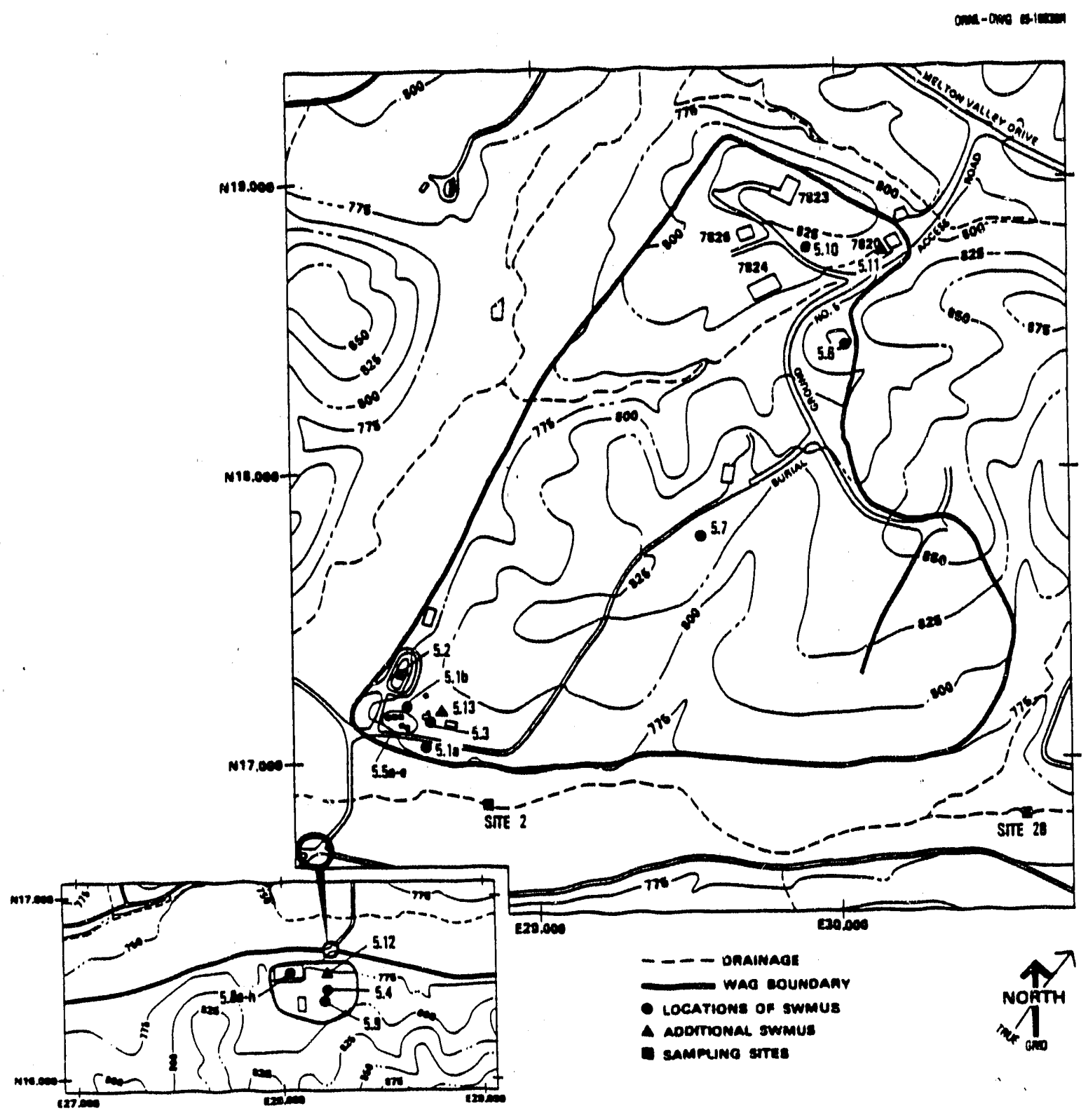

Fig. 2.2 WAG 5-Solid Waste Disposal Area 5, showiag locations of additional SWMUs 5.11, 5.12, and 5.13. 


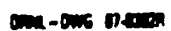

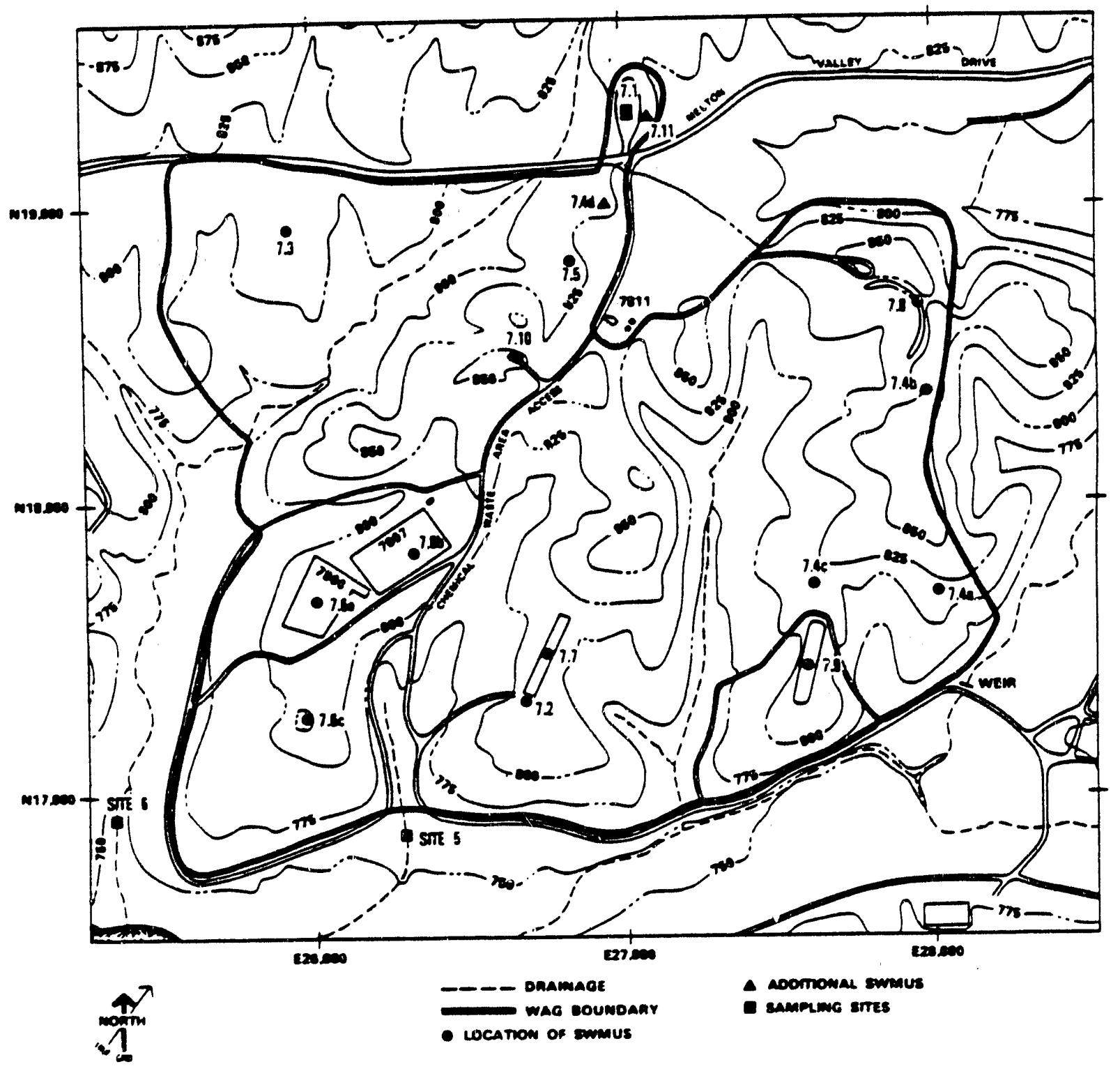

Fig. 23. WAG 7-LLW Pits and Treactes Area, showing locations of ablitional SWMUs 7.4d and 7.11. 


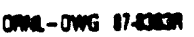

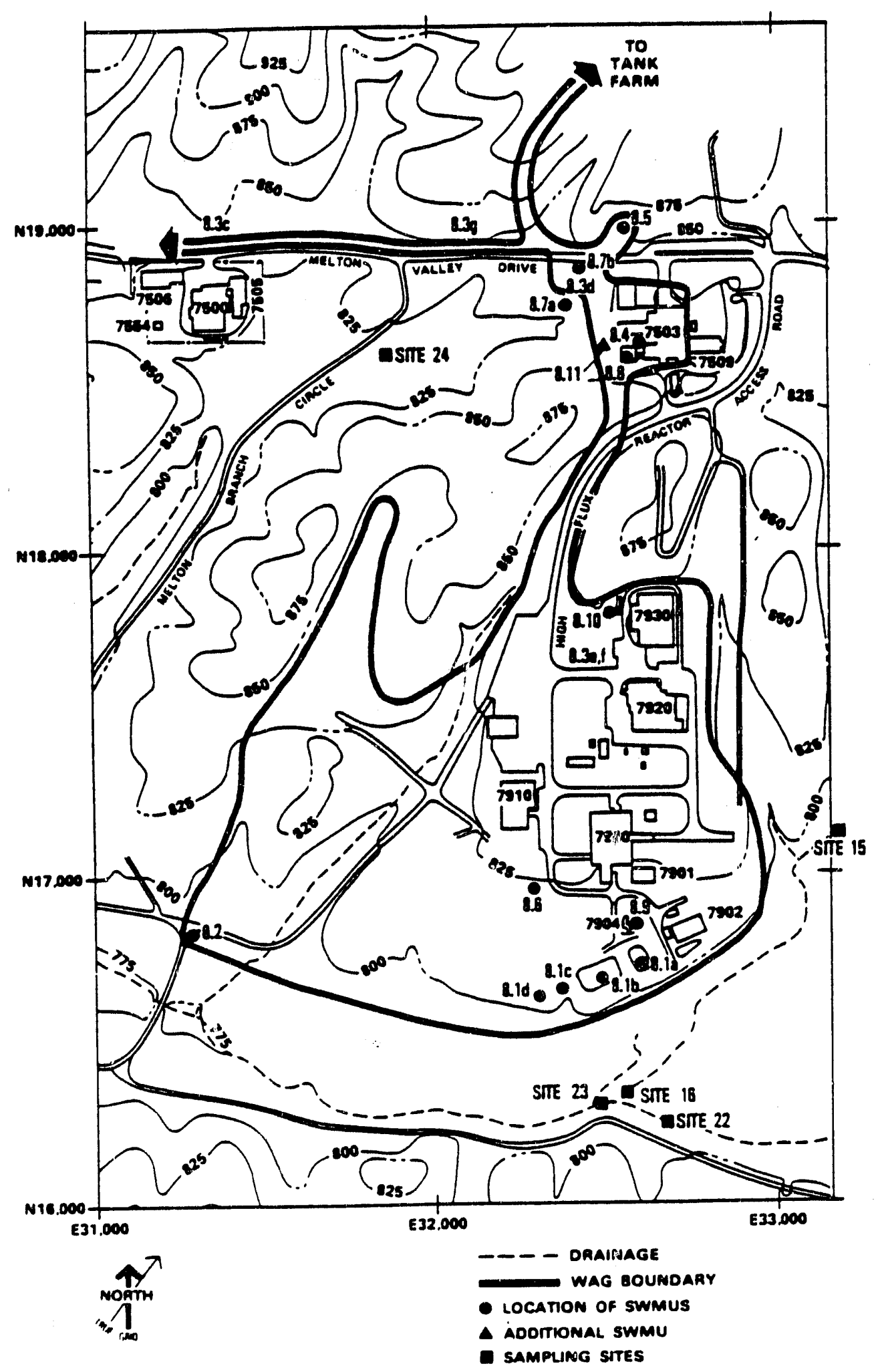

Fig. 24. WAG 8-Metton Valley Area, showing location of additional SWMU 8.11. 


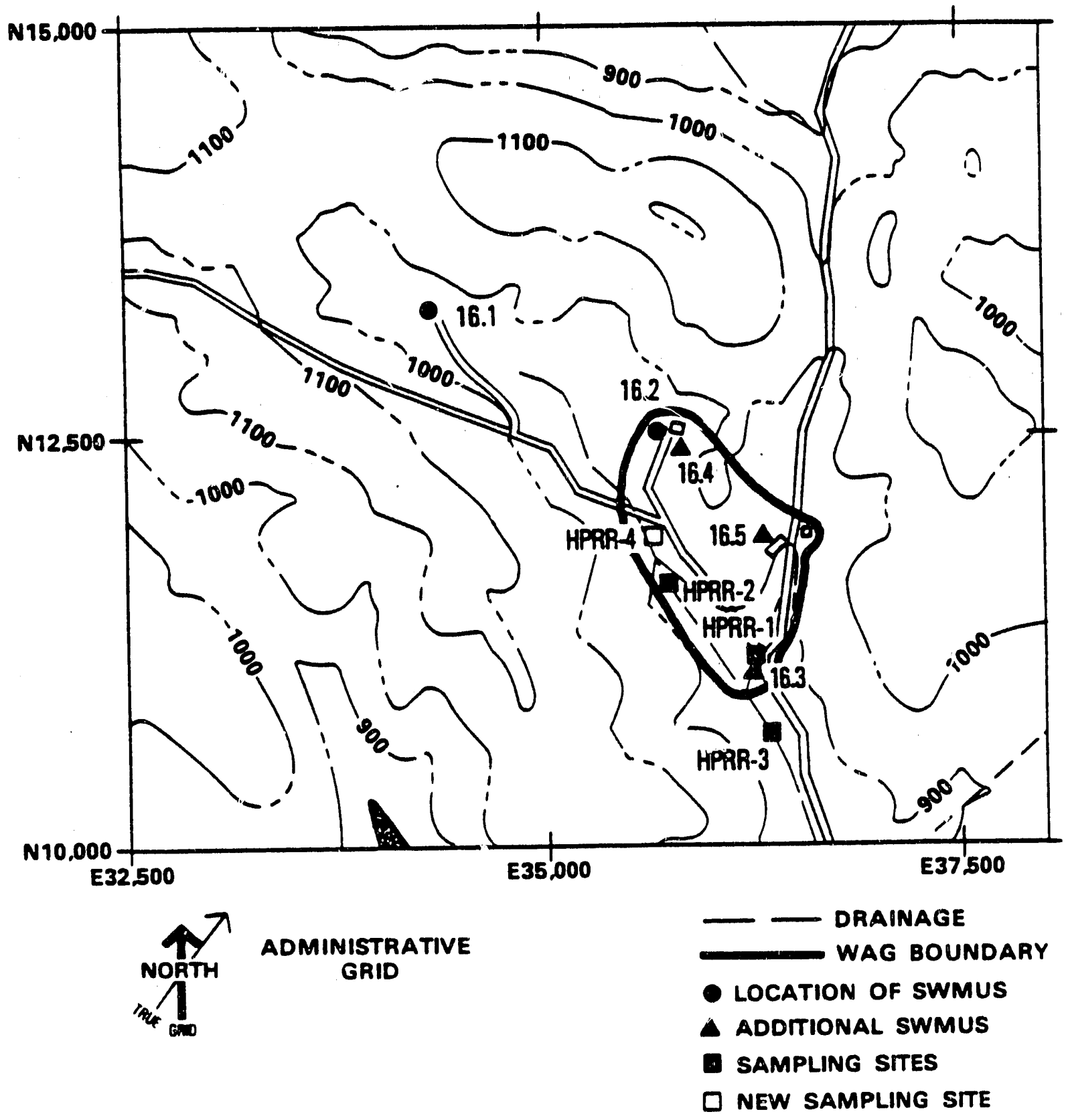

Fig. 25. WAG 16-Health Physics Research Renctor Area, showine location of additional SWMUs 16.3, 16.4, and 16.5 and new sampling site (HPRR-4). 


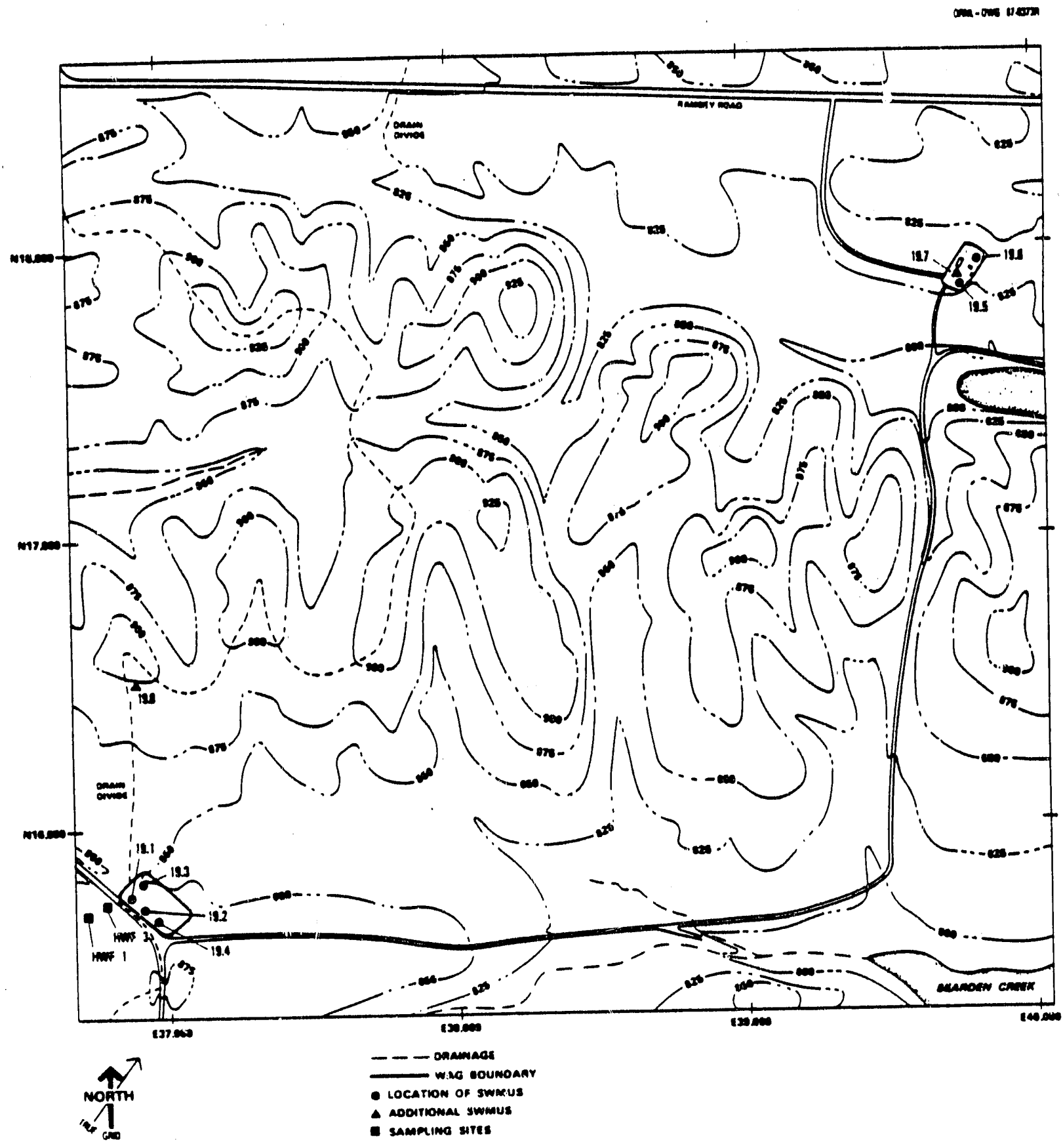

Fig. 2.6. WAG 19-Hazardous Waste Treatment and Stornge Facillities, showing locution of additional SWMUs 19.7 and 19.8. 
repository program and did not involve any waste materials. Although it had previously been identified as an SWMU, current information indicates that it should be removed from the RCRA Section 3004(u) SWMU listing. SWMU 19.8 (Explosive and Shock-Sensitive Waste Detonation Facility) was only recently constructed and has not been used. It will be managed according to present RCRA standards (as well as other pertinent management practices), and a RCRA permit application will be submitted when the new "subpart $\mathrm{X}^{n}$ requirements are finalized. Additional discussion of WAG 19 is included in Sect. 3.

The final new SWMUs are located outside the WAG boundaries that were developed for the RFA. One of these is the Abandoned Bum Pit (OS-1), which is diseussed in Sect. 3, and the second is a septic tank located at a remote facility locally known as "Katy's Kitchen." There is no record of this tank receiving hazardous wastes, and it appears that it should be removed from further consideration under RCRA Section 3004(u).

Although they are not regulated under RCRA Section 3004(u), surplus facilities were included in the RFA site list to maintain a comprehensive inventory of all Oak Ridge National Laboratory (ORNL) potential remedial action sites. In accordance with this poliey, we have listed additional contaminated sites, the Environmental Research Areas (Table 2.2), and have prepared information summaries similar to those included in the RFA (see Appendix B) for surplus facilities. 
Table 22 Environmeutal Research Areas

\begin{tabular}{ll}
\hline Site No. & \multicolumn{1}{c}{ Site description } \\
\hline ER-1 & Ca-45 tagged trees \\
ER-2 & Ca-45 tagged soil and regetation \\
ER-3 & Na-22 contaminated soil \\
ER-1 & Cs-137 bagged leaves study \\
ER-5 & Hg-197 taggeo stream \\
ER-6 & Cs-134 tagged tree \\
ER-7 & Ca-45 tagged forest \\
ER-8 & Cs-137, Fe-59 contaminated animal pens \\
& (McNew Hollow) \\
ER-9 & Hg-203 tagged stream \\
ER-10 & H-3 contaminated trees \\
ER-11 & Cs-137, Co-60 contaminated forest area \\
ER-12 & Cs-134 contaminated oak trees \\
ER-13 & Zn-65 tagged red oak seedlings \\
ER-14 & Cs-134 contaminated pine and oak seedlings \\
ER-15 & Rb-86 contaminated plants \\
ER-16 & Cs-134 contaminated soybean and sorghum \\
ER-17 & Cs-134 contaminated grasses \\
ER-18 & Cs-134 contaminated lichens and mosses \\
ER-19 & Tc-95m contaminated soil and plants \\
ER-20 & Tc-95m uptake studies \\
ER-21 & Tc-95m and I-131 contaminated pasture \\
ER-22 & Cr-51 contaminated grass plots \\
ER-23 & Tc-99 and Np-237 contaminated soil \\
ER-24 & Cs-137 contaminated forest floor \\
ER-25 & Cs-137 contaminated forest understory \\
ER-26 & Cs-137 contaminated meadow \\
ER-27 & Cs-134 contaminated persimmon tree \\
ER-28 & Co-50 and Mn-54 animal study \\
ER-29 & C-14 maintenance-respiration study \\
ER-30 & C-14 sucrose inoculation of oak and pine treer \\
ER-31 & C-14 allocation in white oak trees \\
ER-32 & C-14 allocation in white pine trees \\
ER-33 & C-14 efflux in yellow poplar stand \\
ER-34 & C-14 allocation in woody biomass \\
& plantation species \\
\hline
\end{tabular}




\section{ADDITIONAL SAMPLING SURVEY DATA FOR SELECTED WAGS}

The RFA recommended additional sampling for WAGs 11, 12,13,15, and 19. This section presents the results of these additional surveys along with recommendations concerning regulatory status. Additional data from WAG 16 are included because of the discovery of the Buried Scrap Metal Area. Another category, Other Sites, is used because some of the newly discovered SWMUs do not fit within any current WAG boundary.

\subsection{WAG 11-WHITE WING SCRAP YARD}

Analytical results obtained from water, mud, and stream sediment samples were summarized in the RFA. A follow-up sampling program was conducted in May 1987, and the results are presented in Table 3.1. Five sites (Fig. 3.1) were sampled including one site (WW-2) sampled in the previous

Tabie 3.1. Survey reaults from WAG 11 in 1987

\begin{tabular}{|c|c|c|c|c|c|c|}
\hline Element & BKDG & WW-2 & ww-3 & WW-4 & WW-s & $w W-6$ \\
\hline \multicolumn{7}{|c|}{ Gravels } \\
\hline $\begin{array}{l}\mathrm{Pu}-239^{b} \\
\mathrm{U}-238^{b} \\
\mathrm{Sr}-90^{b} \\
\mathrm{Cd} \\
\mathrm{Cr}^{c} \\
\mathrm{Cu}^{c} \\
\mathrm{Ni}^{c} \\
\mathrm{~Pb}^{c} \\
\mathrm{Zn}^{c}\end{array}$ & $\begin{array}{c}0.63 \\
14.4 \\
5.2 \\
0.05 \\
0.4 \\
0.5 \\
4.8 \\
2.0 \\
3.8\end{array}$ & $\begin{array}{l}0.04 \pm 0.19 \\
66 \pm 3 \\
0.3 \pm 4.5 \\
0.40 \\
0.81 \\
2.8 \\
12 \\
3.6 \\
29\end{array}$ & $\begin{array}{l}0.06 \pm 0.12 \\
6.4 \pm 1 \\
7.9 \pm 6 \\
0.27 \\
1.1 \\
1.1 \\
4.2 \\
<2.0 \\
6.5\end{array}$ & $\begin{array}{l}<0.05 \\
14 \\
6.0 \\
0.22 \\
0.47 \\
0.79 \\
12 \\
<2.0 \\
10\end{array}$ & $\begin{array}{r}0.13 \\
0.46 \\
1.5 \\
6.6 \\
<2.0 \\
6.7\end{array}$ & $\begin{array}{l}0.05 \pm 0.13 \\
3.8 \pm 0.9 \\
2.5 \pm 4.1 \\
0.20 \\
0.45 \\
0.76 \\
10 \\
<2.0 \\
11\end{array}$ \\
\hline \multicolumn{7}{|c|}{$\begin{array}{l}\text { Water } \\
(\mathrm{Bq} / \mathrm{L})\end{array}$} \\
\hline $\begin{array}{l}\text { Pu-239 } \\
\text { U-238 } \\
\text { Sr }-90\end{array}$ & $<0.2$ & & $\begin{array}{c}<0.01 \\
0.014 \pm 0.005 \\
0.09 \pm 0.12\end{array}$ & $\begin{array}{c}<0.01 \\
0.0005 \pm 0.0044 \\
0.06 \pm 0.11\end{array}$ & & $\begin{array}{c}<0.01 \\
0.0036 \pm 0.0061 \\
0.12 \pm 0.12\end{array}$ \\
\hline \multicolumn{7}{|c|}{$\begin{array}{l}\text { Semivolatile organics } \\
\qquad(\mu \mathrm{g} / \mathrm{kg})\end{array}$} \\
\hline \multicolumn{2}{|c|}{ Di-n-butylphthalate } & & 4400 & 4400 & & \\
\hline
\end{tabular}

"Concentrations reported on basis of dry weight of gravel sample. Radionuclides in Bq/ $\mathrm{kg}$. Metals in $\mu \mathrm{g} / \mathrm{g}$.

'Backgrounds estimated from the mean of samples collected at several remote sampling sites (Environmental Surveillance Report-Oak Ridge, 1986).

'Backgrounds estimated from several uncontaminated samples. Values are those typical for Conasauga shaie. 


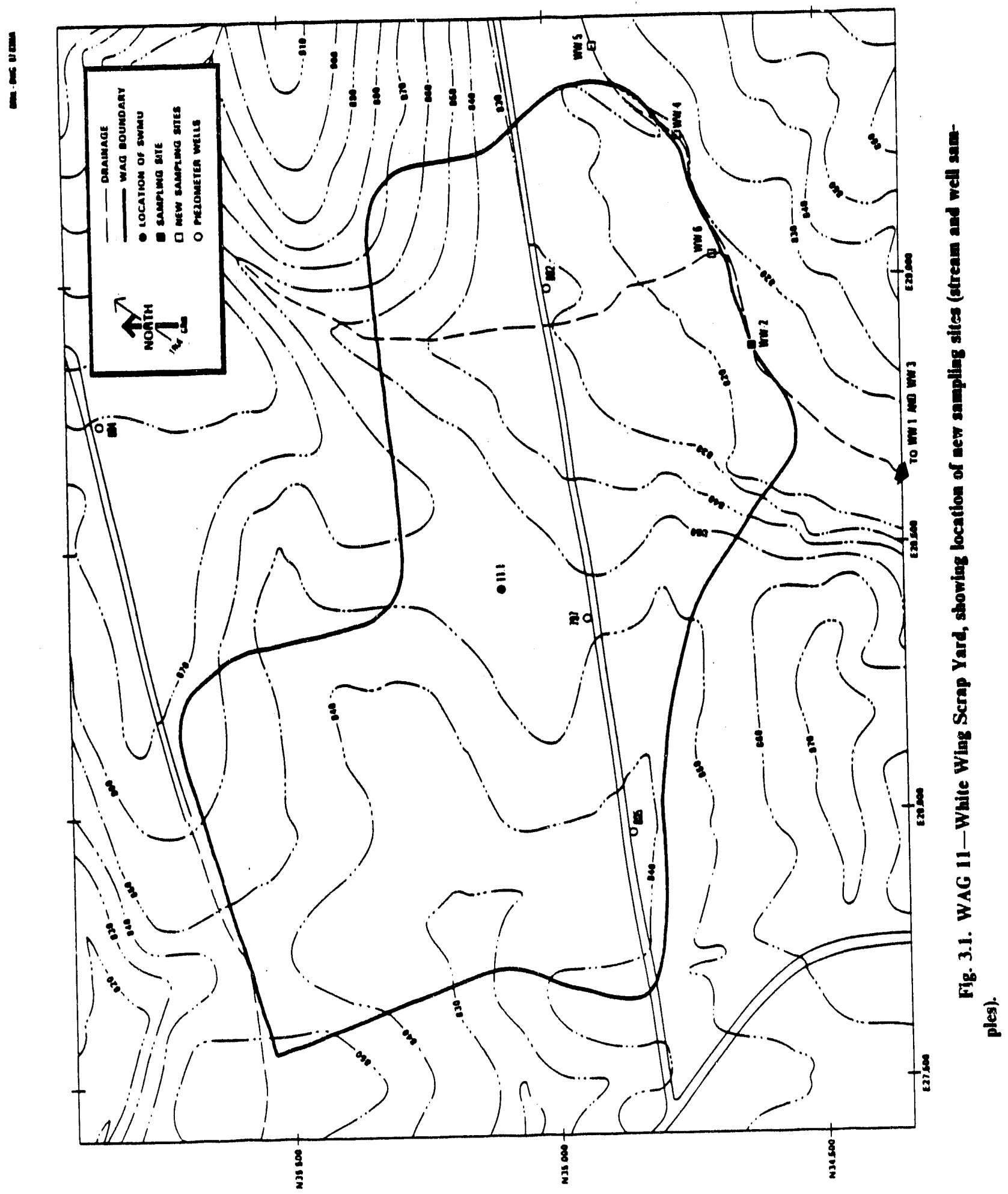


survey. Sites WW-2, WW-6, and WW-4 are located within the WAG. Site WW-5 is slightly upstream, and W-3 is downstream south of the scrap yard. For the extractable inetals from the stream gravel samples, concentrations of $\mathrm{Cd}, \mathrm{Cu}$, and $\mathrm{Zn}$ were 5 to 8 times background levels at WW-2. Cadmium exceeded background levels in all samples but was the highest at WW-2. Remaining metal concentrations that were detected did not exreed 2 times background at any of the sites.

Radionuclide concentrations in the stream graveis were below background levels in most samples. The concentrations of U-238 were about five times background at site WW-2, and Sr-90 levels were slightly above background at WW-3 and WW-4.

As in the previous survey, the only semivolatile organic detected was di-n-butylphthalate, a component of plastic materials that is common in sediments.

Groundwater samples were taken from selected piezometer wells in WAG 11, and the results from a metals analysis are summarized in Table 3.2 (for well locations, consult Fig. 3.1). Most of the values obtained from the downgradient wells are not significantly above those observed in the upgradient well; however, the concentration of chromium in the upgradient well is above the National Interim Primary Drinking Water Standard. Magnesium concentrations in downgradient wells ranged from 20 to 140 times the value observed in the upgradient well.

Analysis of groundwater samples for volatile and semivolatile organics established the presence of three volatile contaminants, methylene chloride, trichloroethylene, and acetone at concentrations of $6 \mathrm{ppb}, 184 \mathrm{ppb}$, and $23 \mathrm{ppb}$ respectively. Only metbylene chloride was detected in more than one sample. Concentrations of all the semivolatile organies were below detection limits. The

Tabie 3.2. Sorvey rewalts from piezometer welb at WAG 11

\begin{tabular}{|c|c|c|c|c|c|c|c|c|}
\hline \multirow{2}{*}{ Well No. } & \multicolumn{8}{|c|}{$\begin{array}{l}\text { Metals }^{e} \\
(\mathrm{mg} / \mathrm{L})\end{array}$} \\
\hline & Al & $\mathrm{Ba}$ & $\mathrm{Cu}$ & $\mathrm{Cr}_{\mathrm{r}}$ & $\mathrm{Fe}$ & $\mathbf{M g}$ & $\mathrm{Mn}$ & $Z_{n}$ \\
\hline 797 & 1.3 & 0.089 & 0.063 & $n d^{b}$ & 1.3 & 19 & 0.076 & 0.035 \\
\hline 802 & 0.57 & 0.029 & 0.054 & . nd & 0.37 & 14 & 0.048 & 0.033 \\
\hline 805 & 0.85 & 0.031 & 0.010 & 0.084 & 0.97 & 2.7 & 0.0 .44 & 0.030 \\
\hline $804^{c}$ & 1.2 & 0.083 & 0.059 & 0.35 & 0.46 & 0.13 & 0.028 & 0.021 \\
\hline
\end{tabular}

'Only those metals that were detected in at least one sample are included. ind - not detected

Upgradient wells. 
concentration of trichloroethylene is significantly above the recently determined allowable limit of 5 $\mathrm{ppb}$ in drinking water.

Previous radiological surveys detected surface radiation levels up to $5 \mathrm{mrad} / \mathrm{h}$; however, the source of these "hot spots" remains undetermined.

Based on the results from previous scoping studies (RFA) and those presented in this Addendum, it appears that WAG 11 is not a significant source of releases of hazardous constituents. There remain, however, uncertainties conceraing the source of elevated levels of $\mathrm{Cr}, \mathrm{Cd}$, some organic contaminants, and surface radiation "hot spots." Further investigations are needed to resolve these concerns. Evidence indicates that an RI Plan is needed for WAG 11.

\subsection{WAG 12-CLOSED CONTRACTORS' LANDFILL}

Results from previous scoping surveys presented in the RFA were inconclusive concerning the possible release of organic contaminants. Accordingly, additional samples were collected at two sites adjacent to the landfill (Fig. 3.2 and Table 3.3) and analyzed for semivolatile organic constituents. As was the case in previous surveys, the only semivolatile crganics detected were the phthalates, a fairly common component found in sediments.

Since a number of piezometer wells have been installed in and around WAG 12, groundwater samples were taken for metals analysis. Relatively high concentrations of $\mathrm{Al}, \mathrm{Ba}, \mathrm{Fe}, \mathrm{Mg}$, and $\mathrm{Mn}$ were found in one of the downgradient wells (915), while elevated levels of Cr were seen in another (913). Volatile organics detected included methylene chloride and 1,2 dichloroethane at concentrations of $7 \mathrm{ppb}$ and $5 \mathrm{ppb}$ respectively. The only semivolatile organic detected was di-nbutylphthalate at a level of $10 \mathrm{ppb}$ (see Table 3.4).

Based on the results presented in the RFA and those of additional surveys, including analysis of groundwater (reported here), it does not appear that WAG 12 is a source of past releases. ORNL recommends that WAG 12 be removed from further consideration as a RCRA Section 3004(u) site.

\subsection{WAG 13-ENVIRONMENTAL RESEEARCH AREAS}

This WAG contains two sites that were handled as SWMUs (13.1 and 13.2) in the RFA; however, ORNL has subsequently determined that these sites are non-SWMUs because they do not fall 


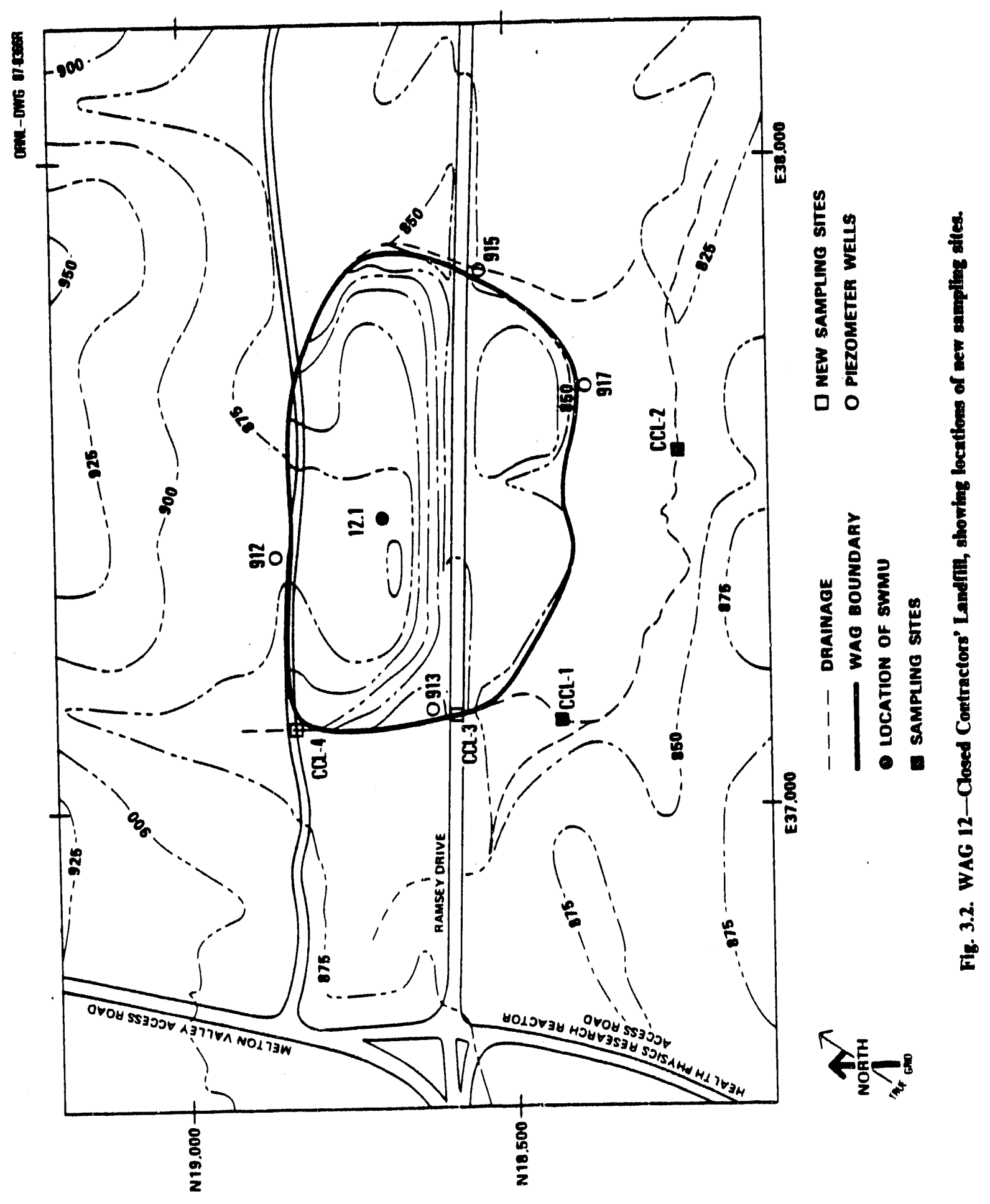


Table 3.3. Survey reculte from pirezometer wells at WAG 12

\begin{tabular}{|c|c|c|c|c|c|c|c|c|}
\hline \multirow{2}{*}{ Well No. } & \multicolumn{8}{|c|}{$\begin{array}{l}\text { Metalsa } \\
(\mathrm{mg} / \mathrm{L})\end{array}$} \\
\hline & Al & Ba & $\mathrm{Cu}$ & $\mathrm{Cr}$ & Fe & Mg & $\mathbf{M n}$ & $Z_{a}$ \\
\hline $\begin{array}{l}913 \\
917 \\
915 \\
912^{6}\end{array}$ & $\begin{array}{l}\text { ad } \\
0.32 \\
8.5 \\
0.17\end{array}$ & $\begin{array}{l}0.079 \\
0.17 \\
0.31 \\
0.060\end{array}$ & $\begin{array}{l}\text { ad } \\
\text { ad } \\
\text { ad } \\
\text { ad }\end{array}$ & $\begin{array}{l}0.14 \\
0.065 \\
\text { ad } \\
\text { ad }\end{array}$ & $\begin{array}{c}0.045 \\
0.53 \\
49 \\
0.22\end{array}$ & $\begin{array}{c}13 \\
5.2 \\
19 \\
3.9\end{array}$ & $\begin{array}{c}0.016 \\
0.066 \\
27 \\
0.023\end{array}$ & $\begin{array}{c}\text { nd } \\
\text { nd } \\
0.025 \\
\text { nd }\end{array}$ \\
\hline
\end{tabular}

Only those metals that were detected in at least one sample are included.

bad = not detected

Upsradient wells.

Table 3.4. Survey resolts from WAG 12 in 1987

\begin{tabular}{|c|c|c|c|}
\hline Element & Background & $\mathrm{CCL} 3$ & $\mathrm{CCL}_{4}$ \\
\hline \multicolumn{4}{|c|}{$\begin{array}{l}\text { Water } \\
(\mathrm{Bq} / \mathrm{L})\end{array}$} \\
\hline $\begin{array}{l}\text { Co-60 } \\
\text { Sr-90 } \\
\text { Cs- } 137\end{array}$ & $\begin{array}{l}<0.2 \\
<0.2 \\
<0.2\end{array}$ & $\begin{array}{c}<0.2 \\
0.08 \pm 0.12 \\
<0.3\end{array}$ & \\
\hline \multicolumn{4}{|c|}{$\begin{array}{l}\text { Semivolatile organics } \\
(\mathrm{\mu g} / \mathrm{kg})\end{array}$} \\
\hline \multicolumn{2}{|c|}{$\begin{array}{l}\text { Di-y -hutylphthalate } \\
\text { Bis(2-ethylhexyl) } \\
\text { phthalate }\end{array}$} & $\begin{array}{l}4600 \\
7000\end{array}$ & $\begin{array}{l}4400 \\
1100\end{array}$ \\
\hline
\end{tabular}

Eackgrounds estimated from the mean of samples collected at several remote sites (Environmental Surveillance Report-Oak Ridge, 1986).

under the guidelines used to identify SWMUs. Preliminary survey data detected minimal contamination from site 13.2, but levels of Cs-137 at site 13.1 were considerably above background. Recommendations in the RFA for WAG 13 included collection of additional samples to better define the extent of Cs-137 migration from site 13.1. Additional sampies were taken from two locations that are between site 13.1 and the original sampling point (Fig. 3.3), and the results are shown in Table 3.5. It is evident that Cs-137 has migrated from site 13.1, as the concentrations in the soil are 15 to 60 times background.

Based on the results from the sampling surveys, ORNL recommends that interim corrective measures be employed at site 13.1 to limit further radionuclide migration. Since all contaminated 


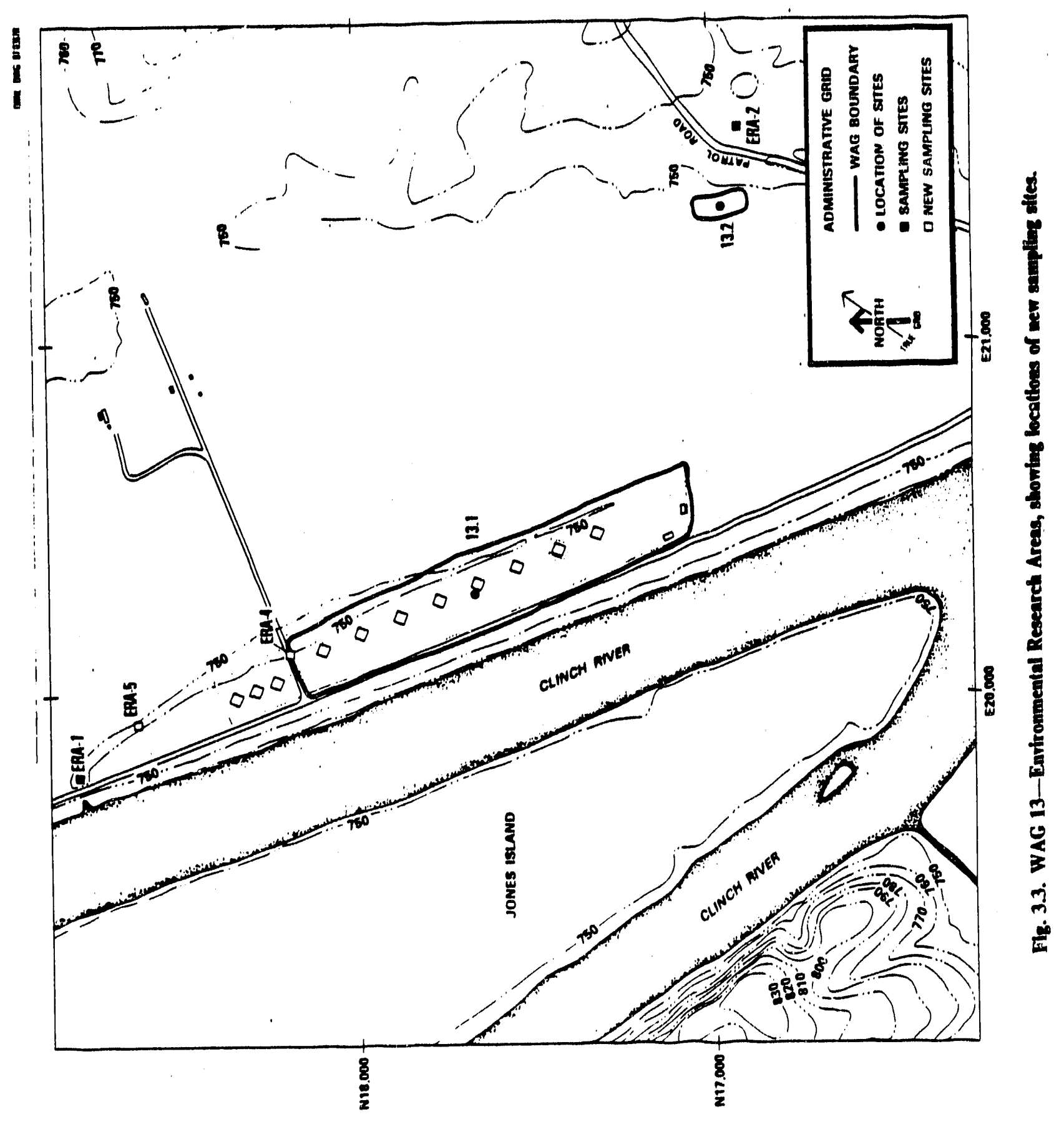


Table 3.5. Soil survey results from WAG 13 in 1987 (Bq/ kg)

\begin{tabular}{lccc}
\hline Elemeat & Background $^{a}$ & ERA-4 & ERA-5 \\
\hline Co-60 & $<2$ & $<2$ & 2 \\
$\operatorname{Co} 137$ & 40.7 & $580 \pm 10$ & $2300 \pm 100$ \\
\hline
\end{tabular}

a Backgrounds estimated from the mean of samples collected at several remote sites (Environmental Surveillance Report-Oak Ridge, 1986).

sites within the WAG boundary are non-SWMUs, WAG 13 should be deleted from further consideration under RCRA Section 3004( $u_{i}$. However, continued surveillance and corrective action are warranted and will be implemented under CERCLA (SARA) and applicable DOE Orders.

\subsection{WAG 15-ORNL FACIITTIES AT THE Y-12 PLANT}

The SWMUs at the Y-12 Plant include areas where surplus transformers and capacitors containing PCBs were located and Building 9201-2, where ORNL operated a cyclotron using Z-oil as the coolant. The only documented release was an instance where records indicate that PCBcontaminated oils leaked from one transformer located at the SY-300 Scrap Yard. Oil contained in this transformer had PCB concentrations ranging from 2 to $17 \mathrm{ppm}$.

In order to determine the possible existence of the residual PCB contamination resulting from the reported oil leak and other sites where transformers and capacitors were stored, several soil samples were collected and analyzed for PCBs (PCB-1254 and PCB-1260). Several samples were taken in the area of the oil leak and in areas where there was no visible evidence of contamination. Concentrations ranged from less than $1 \mathrm{ppm}$ to $10 \mathrm{ppm}$. Only 2 samples out of the total of 14 had concentrations greater than $3 \mathrm{ppm}$, and both of these were outside the known oil leak site. Based on the results of this preliminary survey, it is concluded that the ORNL SWMUs (transformer sites) at the $Y-12$ Plant are not a source of continuing release.

Since the submittal of the RFA, arrangements have been made with Environr:ental Protection personnel at the Y-12 Plant to include these sites in their Remedial Action Program. Our assessment of these SWMUs will be forwarded to them to be integrated into their plans. Pursuant to the discussions with Y-12 Plant personnel, WAG 15 is being removed from the ORNL RAP list.

Other non-SWMU sites will be covered under the Surplus Facilities Management Program. 


\subsection{WAG 16-HEALTH PHYSICS RESEARCH REACTOR AREA}

In the RFA, it was recommended that WAG 16 be omitted from further consideration as a RCRA Section 3004(u) site. However, an additional SWMU (16.3, Buried Scrap Metal Area) was discovered in this WAG. Thus, additional soil and stream gravel samples were collected (see Fig. 2.5 for locations) and analyzed for metals, organies, and radionuclides (Table 3.6). No organies

Talle 36. Soll and graved arvey realts from WAG 16 i 1987

\begin{tabular}{|c|c|c|c|}
\hline Element & Background & HPRR-3 & HPRR 4 \\
\hline $\begin{array}{l}\mathrm{Co-6}-60^{b} \\
\mathrm{Sr}-90^{b} \\
\mathrm{C}_{-}-137^{b} \\
\mathrm{Cd}^{c} \\
\mathrm{Cr}^{c} \\
\mathrm{Cr}^{c} \\
\mathrm{Ni}^{c} \\
\mathrm{~Pb}^{c} \\
\mathrm{Zn}^{c}\end{array}$ & $\begin{array}{c}<2 \\
5.2 \\
40.7 \\
0.5 \\
1.4 \\
0.5 \\
2.6 \\
2.4 \\
17\end{array}$ & $\begin{array}{l}<4 \\
0.15 \\
1.8 \\
1.4 \\
1.5 \\
4.3 \\
16\end{array}$ & $\begin{array}{c}<1 \\
11 \pm 1\end{array}$ \\
\hline
\end{tabular}

Concentrations reported on basis of dry weight of gravel enpie. Recionuclides in Bq/k\&. Metals in $\mu 8 / 8$.

Beckgrounds estimated from the samples collected at several remote sampling sites (Environmental Surveillance Repon-Oak Ridge, 1986).

Backerounds estimated from several uncoatuminated samples. Values are those typical of the Knox geologic group.

were detected, and the concentrutions of metals that were detected were at background levels. No significant radioactivity was present in any of the samples. These results and those of the previous survey confirm that there is no evidence of past or continuing releases. There is no change in our recommendation that this WAG be removed from further consideration as a RCRA Section $3004(u)$ site.

\subsection{WAG 19-HAZARDOUS WASTE TREATMENT AND STORAGE FACILTTIES}

Two additional SWMUs have been added to WAG 19 (Fig. 2.6). SWMU 19.8, the Explosive and Shock-Sensitive Waste Detonation Facility, has not been used. Future use will be according to all applicable regulations and no releases should occur. If releases do occur, corrective action will be taken as outlined in future permit applications. SWMU 19.7; Soil Injection of Radioactive Gas. 
originally listed as an SWMU, should be removed from the list because it bas been determined that solid waste was not a part of the experiments conducted at this site (see Sect. 1.2 and the Summary Sheet).

An additional soil sample was collected (for sampling site location, see Fig. 2.6) and analyzed for organic constituents. Di-n-butylphthalate was the only organic detected; the concentration was $2900 \mu \mathrm{g} / \mathrm{kg}$. It is recommended that WAG 19 be omitted from further consideration as a RCRA Section $3004(u)$ site.

\subsection{OTHER SITES-ABANDONED BURN PIT}

This SWMU was originally placed in WAG 17, ORNL Services Area. Since it is not located within the boundaries of WAG 17, the Burn Pit is considered separately in this report. The site is located north of WAG 17 on Chestnut Ridge Road in the area of the Sanitary Waste Compactor (see Fig. 3.4).

The site was used for burning combustible trash. There are no records as to the exact nature of the material burned, but it has been reported (interviews with retired employees) that on at least two oceasions laundry materials contaminated with very-low-level radioactivity were burned in the pit. Operations ceased when the Sanitary Waste Compactor was placed on the site.

The SWMU is located in the same geologic setting as WAG 17 and WAG 1 (the ORNL Main Plant Area). The underlying formation is apparently the Chickamauga Limestone. The major surface water drainage is to the west into White Oak Creek.

Soil samples were collected from two sites, OSA-2 and OSA-3 (Fig. 3.4) and analyzed for metals, organies, and radionuclides. Results from this analysis are summarized in Table 3.7. Concentrations of $\mathrm{Cd}, \mathrm{Cu}, \mathrm{Pb}$, and $\mathrm{Zn}$ were significantly above background in the sample taken from site OSA-2. Except for cadmium, the sample taken from OSA-3 was near background levels. Samples from both sites showed slightly elevated Cs-137 activity. No organics were detected in either sample.

Sufficient uncertainties exist concerning the past history and the nature of releases at this site to warrant additional characterization. It is recommended that additional sampling of this site be undertaken before placing it into or removing it from the RI process. 


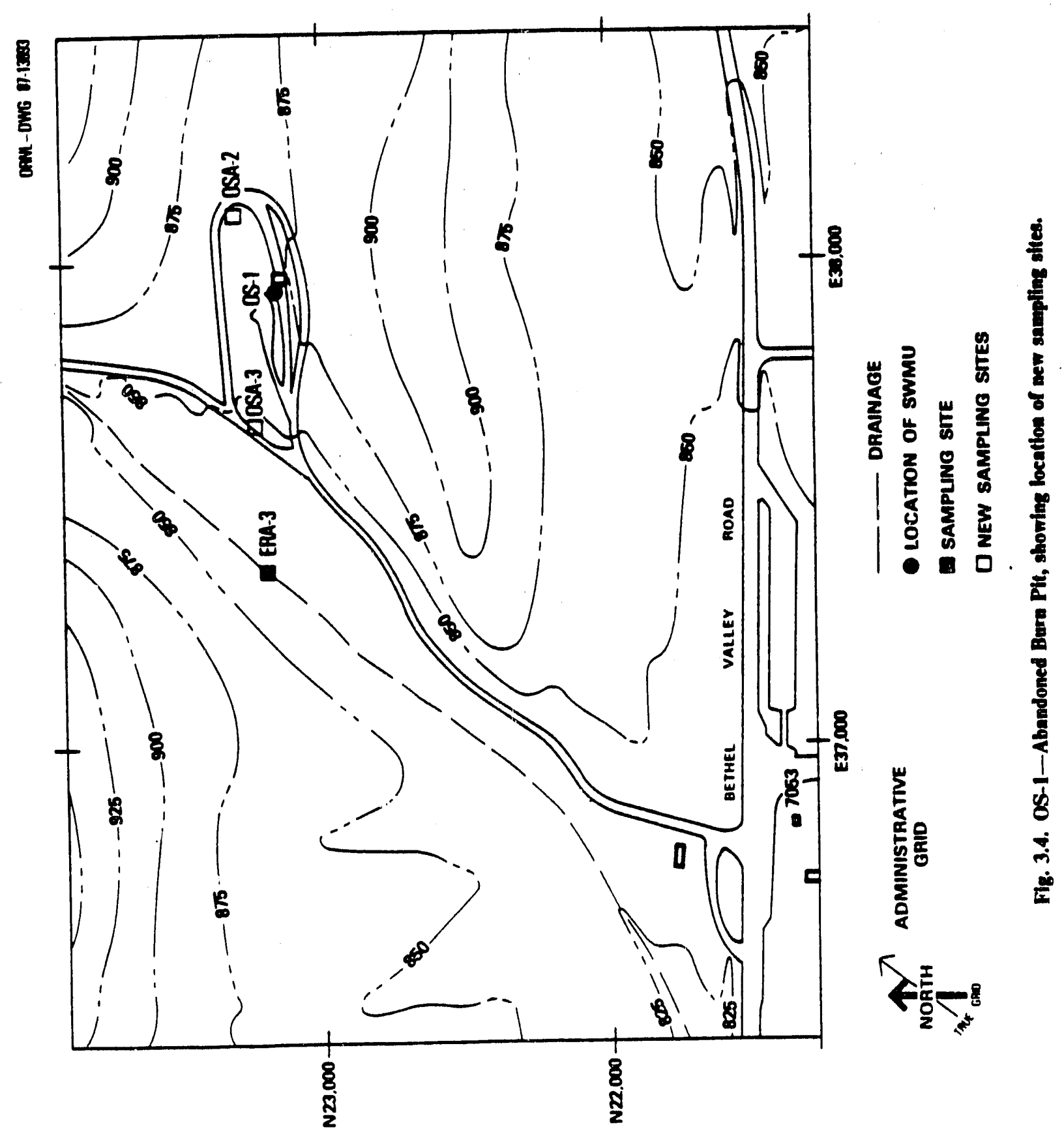


Table 3.7. Soll survey results from Abandoned Burn Pit in 1987

\begin{tabular}{lccc}
\hline Element & Background & OSA-2 & OSA-3 \\
\hline $\mathrm{C} 0-60^{b}$ & $<2$ & $<2$ & $<1$ \\
$\mathrm{Sr}-90^{b}$ & 5.2 & $6.2 \pm 5.1$ & $11 \pm 5$ \\
$\mathrm{C}-137^{b}$ & 40.7 & $43 \pm 3$ & $17 \pm 1$ \\
$\mathrm{Pu}-239^{b}$ & 0.63 & $1.5 \pm 0.5$ & $0.01 \pm 0.35$ \\
$\mathrm{U}-238^{b}$ & 14.4 & $0.06 \pm 0.20$ & $1.1 \pm 0.5$ \\
$\mathrm{Cd}^{c}$ & 0.05 & 1.4 & 0.44 \\
$\mathrm{Cr}^{c}$ & 0.4 & 2.6 & 1.2 \\
$\mathrm{Cu}^{c}$ & 0.2 & 22 & 1.8 \\
$\mathrm{Ni}^{c}$ & 0.9 & 3.5 & 1.5 \\
$\mathrm{~Pb}^{c}$ & 2.4 & 21 & 5.1 \\
$\mathrm{Zn}^{c}$ & 3.6 & 31 & 16 \\
\hline
\end{tabular}

Concentrations reported on basis of dry weight of gravel sample. Radionuclides in $\mathrm{Bq} / \mathrm{kg}$. Metals in $\mu \mathrm{g} / \mathrm{g}$.

Backgrounds estimated from the samples collected at several remote sampling locations (Environmental Surveillance Report-Oak Ridge, 1986).

Backgrounds estimated from several uncontaminated samples. Values are those typical of Chickamauga lin nestone. 


\section{REVISION OF WAG BOUNDARY}

In the RFA, WAG 2 was identified as consisting of two SWMUs: (1) SWMU 2.1, which includes White Oak Lake (WOL), White Oak Dam (WOD), and the embayment (the portion of WOC from WOD to where it empties into the Clinch River), and (2) SWMU 2.2, which is the area encompassed by the stream channels of White Oak Creek and Melton Branct. Since Fig. 3.3 in the RFA did not show the embayment in its entirety, a revised map of WAG 2 that includes the embayment is shown in Fig. 4.1 of this Addendum. These revisions will also be reflected in the amended topographic maps (RFA Volume 2) that will be submitted at a later time. 


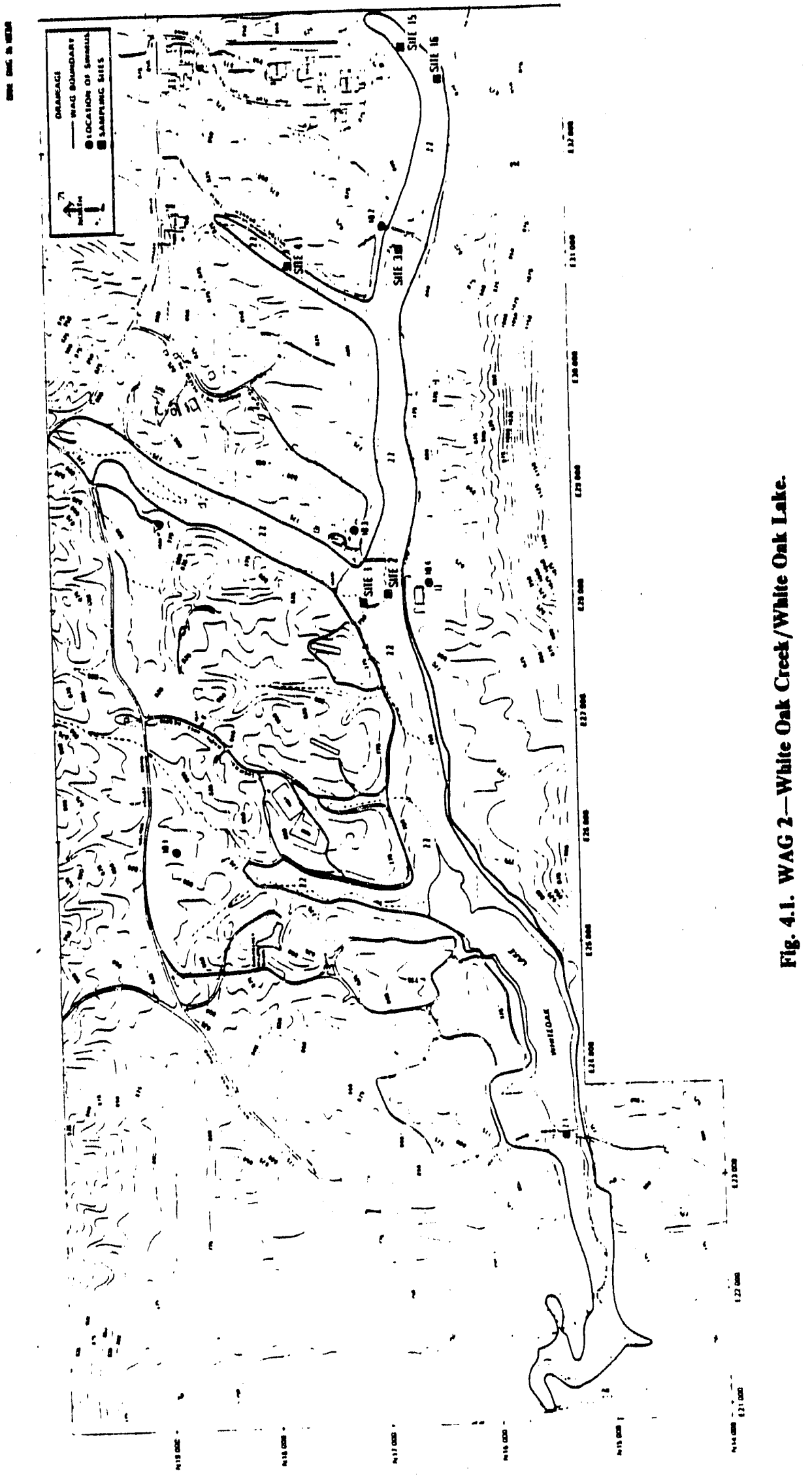




\section{SUMMARY}

\subsection{REGULATORY STATUS OF ADDITIONAL SWMUS AND SELECTED WAGS}

Summary sheets for the 16 additional SWMUs that were not described in the RFA are included in Appendix A. Included in Appendix B are summary sheets for 34 Environmental Research Areas. Although little or no contamination remains at the non-SWMU sites (summarized in Table B.1, Appendix B), they are listed for the purpose of maintaining a complete inventory of potential contaminated sites.

In Table 5.1, the additional SWMUs are listed along with recommendations concerning any future RCRA Section 3004(u) remedial actions. In the RFA, ORNL suggested additional sampling at several of the WAGs before making recommendations concerning further remedial actions under

Table 5.1. Recomneaded actions for additioad SWMU:

\begin{tabular}{|c|c|c|c|}
\hline SWMU & Description & $\begin{array}{l}\text { Recommended } \\
\text { action }\end{array}$ & Comment \\
\hline 1.55 & Septic tank & Delete & No hazardous materials \\
\hline $1.56 \mathrm{a}, \mathrm{b}$ & $\begin{array}{l}\text { Inactive LLW } \\
\text { tanks }\end{array}$ & $\begin{array}{l}\text { Include in } \\
\text { RI for WAG } 1\end{array}$ & $\begin{array}{l}\text { Tanks are empty but are } \\
\text { internally contaminated }\end{array}$ \\
\hline 5.11 & Septic tanks & Delete & No hazardous materials \\
\hline 5.12 & Septic tank & Dolete & No hazardous materials \\
\hline 5.13 & Septic tank & Delete & No hazardous materials \\
\hline $7.4 d$ & Leak site & $\begin{array}{l}\text { Include in } \\
\text { RI for WAG } 7\end{array}$ & Radionuclides present \\
\hline 7.11 & Septic tank & Delete & No hazardous materiais \\
\hline 8.11 & Septic tank & Delete & No hazardous materials \\
\hline 16.3 & Buried scrap metal & Delete & No evidence of releases \\
\hline 16.4 & Septic tank & Delete & No bazardous materials \\
\hline 16.5 & Septic tank & Delete & No hazardous materials \\
\hline 19.7 & $\begin{array}{l}\text { Soil injection } \\
\text { of gas }\end{array}$ & Delete & No hazardous materials \\
\hline 19.8 & $\begin{array}{l}\text { Detonation } \\
\text { Facility }\end{array}$ & No RI needed & New facility \\
\hline OS.! & Old Burn Pit & $\begin{array}{l}\text { Additional } \\
\text { sampling }\end{array}$ & $\begin{array}{l}\text { Nature and release of } \\
\text { hazardous material } \\
\text { uncertain }\end{array}$ \\
\hline OS.2 & Septic tank & Delete & No hazardous materials \\
\hline
\end{tabular}


RCRA Section 3004(u). Additional sampling has been completed and the analytical results are described in Sect. 3. This information, along with that from previous surveys, is the basis for further recommendations concerning the need for additional RCRA Section 3004(u) evaluations. The information summarized in Table 5.2 completes ORNL's assessment of the regulatory status of the 20 WAGs. Changes from those contained in Table 5.2 of the RFA include WAGs 11, 12, 13, 15, and 19; there are no changes in the remaining 15 WAGs.

\section{$5.2 \mathrm{RI} / \mathrm{FS}$ SCHEDULE REVISIONS}

In the RFA a tentative schedule for the completion of Phase IIA (RI or RFI Plans) was submitted. Several completion dates shown in Table 5.3 of the RFA have been revised to reflect revisions to the subcontract award for performing the RI/FS at the ORNL complex; changes in relative priority of some of WAGs, i.e., WAGs 2, 4, and 5; and consideration given to cost-effective resource utilization during preparation of RI/RFI Plans. These revisions are shown in Table 5.3. 


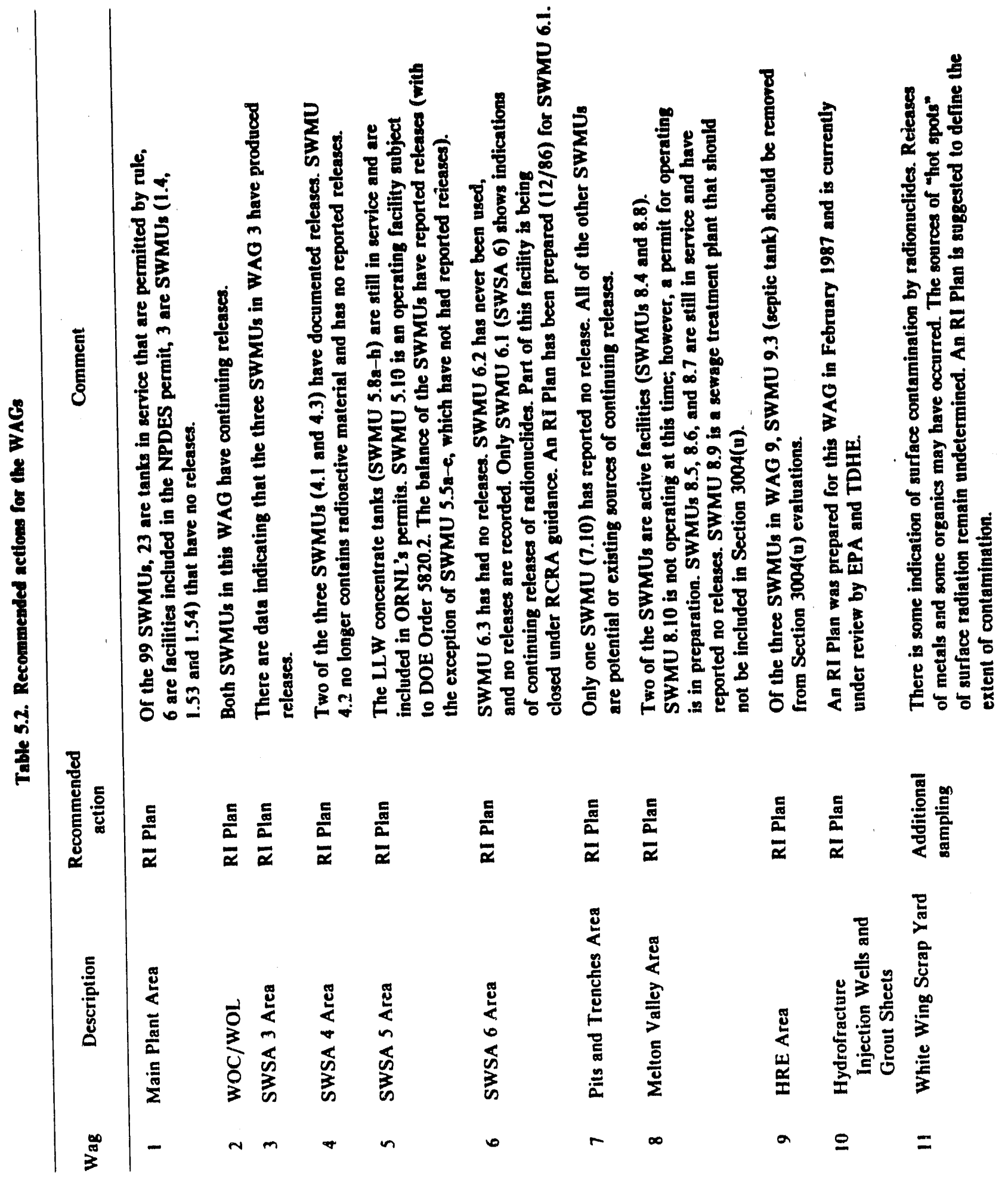




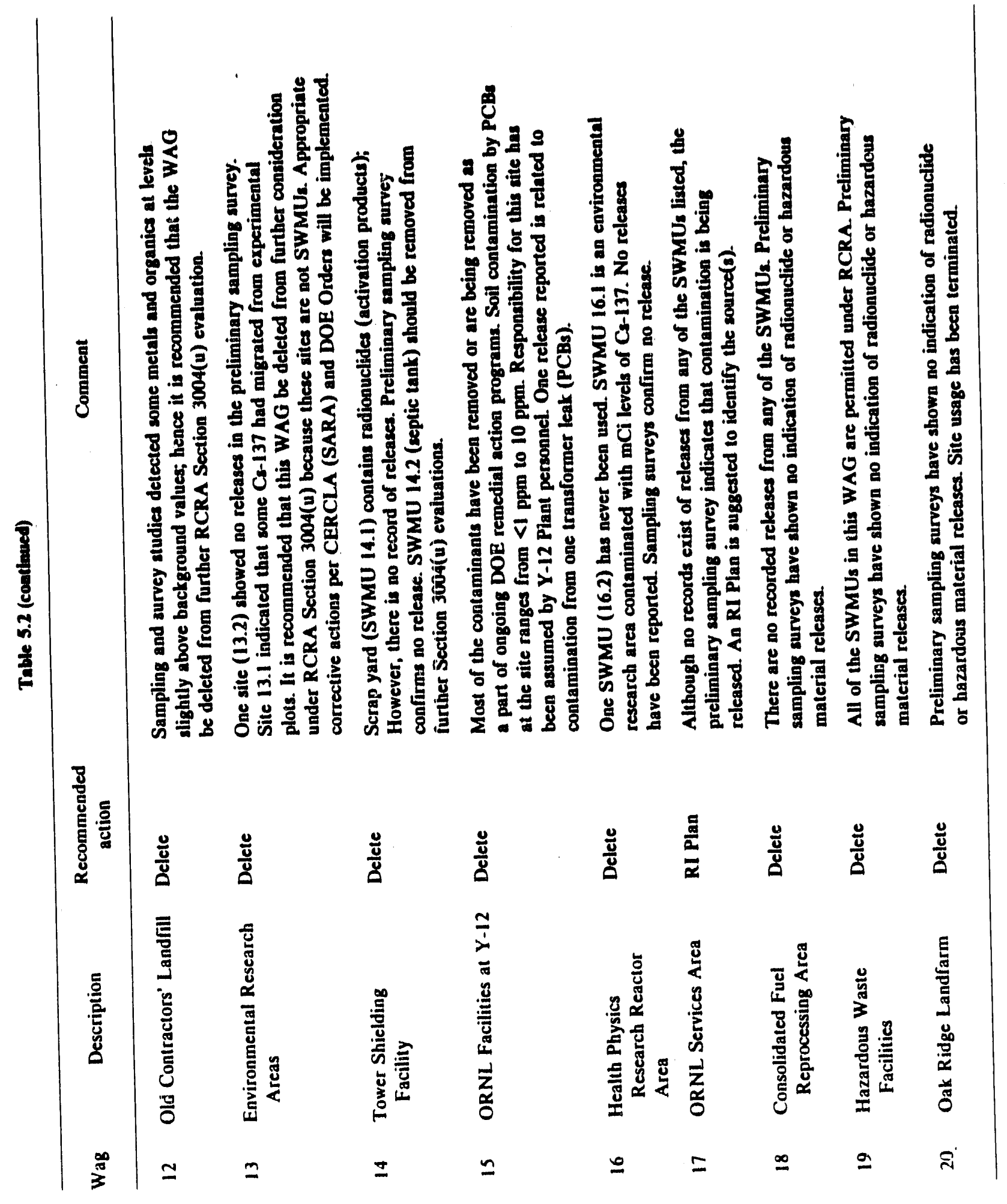


Table 5.3. Preliminary ectedules for ORNL Remedial Investigations/Feaulbility Stady

\begin{tabular}{|c|c|c|}
\hline \multirow{3}{*}{ Waste Area Groupings } & \multicolumn{2}{|c|}{$\begin{array}{l}\text { Completion schedules by phases }{ }^{a, b} \\
\text { (month/year) }\end{array}$} \\
\hline & I & IIA \\
\hline & RFA & (RI or RFI) \\
\hline 1 Main Plant Area & $4 / 87$ & $12 / 87$ \\
\hline $\begin{array}{l}2 \text { White Oak Creek and } \\
\text { White Oak Lake }\end{array}$ & $4 / 87$ & $9 / 88$ \\
\hline 3 Solid Waste Storage Area 3 & $4 / 87$ & $6 / 88$ \\
\hline 4 Solid Waste Storage Area 4 & $4 / 87$ & $4 / 88$ \\
\hline 5 Solid Waste Storage Area 5 & $4 / 87$ & $3 / 88$ \\
\hline 6 Solid Waste Storage Area 6 & $4 / 87$ & $12 / 86$ \\
\hline 7 LLW Pits and Trenches Area & $4 / 87$ & $9 / 88$ \\
\hline 8 Melton Valley Area & $4 / 87$ & $9 / 88$ \\
\hline 9 Homogeneous Resctor. & $4 / 87$ & $5 / 88$ \\
\hline Experiment Area & & \\
\hline 10 Hydrofracture Injection & $4 / 87$ & $2 / 87$ \\
\hline 11 White Wing Sorap Yard & $8 / 87$ & $12 / 88$ \\
\hline $\begin{array}{l}12 \text { Closed Contractors' } \\
\text { Landfill }\end{array}$ & $8 / 87$ & $c$ \\
\hline $\begin{array}{l}13 \text { Environmental Research } \\
\text { Areas }\end{array}$ & $8 / 87$ & $d$ \\
\hline 14 Tower Shielding Facility & $4 / 87$ & $c$ \\
\hline 15 ORNL Froilities at $Y-12$ & $8 / 87$ & $c$ \\
\hline $\begin{array}{l}16 \text { Health Physics Rewearch } \\
\text { Reactor Area }\end{array}$ & $4 / 87$ & $c$ \\
\hline 17 ORNL Services Area & $4 / 87$ & $12 / 88$ \\
\hline $\begin{array}{l}18 \text { Consolidated Fuel } \\
\text { Reprocessing Area }\end{array}$ & $4 / 87$ & c \\
\hline 19 Hazardous Waste & $8 / 87$ & $c$ \\
\hline 20 Oak Ridge Landfarm & $4 / 87$ & $c$ \\
\hline
\end{tabular}

-All schedules following completion of Draft Phase IIA (RI or RFI plans) are tentative and subject to change based on DOE and regulatory agency reviow/negotiations. All RCRA units within a grouping subject to now or interim status permit requirements will also adhere to the applicable permit requirements.

'Comparison between phases in DOE Order 5480.14, CERCLA, and RCRA Section 3004(u):

- Phase $I$ is comparable to the EPA's RCRA Facility Assessment (RFA). RFA report covering all units will be provided to EPA in April 1987.

- Phase IIA is comparable to the EPA's Remedial Investigation (RI) Plan under CERCLA or the RCRA Facilities Investigation (RFI) Plan.

No further action is deemed necessary (Table 5.2).

No further action under RCRA Section 3004(u) is deemed necessary since the ERAs are not SWMUs. Appropriate corrective actions per CERCLA (SARA) and applicable DOE Orders will be implemented. 
APPENDIX A

SWMUs IDENTIFIED SINCE RFA WAS ISSUED 
EPA II.A.1 DATA SUMMARY SHEET

WAG D Number: 1

WAG Narne: Main Plant Area

SWMU DD Number: 1.65

SWMU Name:Septic Tank-Bullditis Sis07

Location of Unit: The septic tank is located southwest of Bullding $5505 \mathrm{in}$ the Main Plant Area. The OPNL orid coordinates are N 20,810 and E 33,090.

General Dimensions and Capactios: Tank is a concrete structure with a capactity of $750 \mathrm{gal}(284 \mathrm{~L} \mathrm{~L})$.

Function of the SWMU: Septic tank ts used to collect and dispose of raw domeetic sewage from Bulliting 5505.

Dates of Operation: Septio tank was hatalled in 1987 and is atill in use (20 years).

Waste Characteriatics: Only domeetic sewage from Bulloling 5605 has been collocted/stored in the tank. No hazardous or radioactive wastes have been added to the system.

Release Date: There have been no reported leaks or releases. 
EPA II.A.1 DATA SUMMARY SHEET

WAG ID Number: 1

WAG Nama: Main Plant Area

SWMU ID Number: $1.56 a$

SWMU Name: Inactive LWW Collection Tank W-19

Location of Unit: Tank is located north of Bullding 3517 (Fiasion Product Development Laboratory) and weet of Bulding 3505 (Metal Recovery Facillty). ORNL grid coordinates are N 21,815 and E 31,008.

General Dimensions and Capactica: Tank is $7.5 \mathrm{ft}$ wide by $8.6 \mathrm{ft}$ long and is constructed of stainieas steel. The tank is installed in a concrete veutt. Capactly of the tank is $2250 \mathrm{gal}(8520 \mathrm{~L})$.

Function of the SWMU: This tank [and W-20 (SWMU 1.58b)] were installed for the purpoes of collecting LLW solutions from Bulling 3505. After closure of the Motal Recovery Facilfty in 1880, the tanks were used for a perlod of $1-2$ years by the Fission Proctuct Development Laboratory for LLW collection.

Dates of Operation: The Metal Recovery Facilty was constructed in 1951 and commiesioned in 1962. The tanks collected wastes from 1962 unth the earty 1980s, when they were removed from service.

Waste Characterlatica: The tanks are reportedly empty but they remain internally contaminated. Prt mary wastes handled by the Motal Recovery Facilly contained Sr-90, Cr-137, Pu-238, Pu-239, and Pu-240. In addition, wastes from the Fission Product Development Laboratory contained sionificant quenttilies of Co-144 and Pm-147.

Release Data: There have been no reported loaks or releases. 
EPA H.A.1 DATA SUMMARY SHEET

WAG D Number: 1

WAG Nemo: Main Plant Area

SWMU D Number: $1.56 b$

SWMU Name: Inactive UWW Colloction Tank W-20

Locsticn $*$ Unit: Tank is beated north of Building 3517 (Fiseion Product Development Laboratory) and weot of Builing 3505 (Metal Recovery Facility). OFNL Grid coordinates are iN 21,805 and E 31,008.

General Dimensions and Capacitios: Tank is $7.5 \mathrm{Ht}$ wide by $8.5 \mathrm{Ht}$ long and is constructed of atainibes steel. The tank is installod in 8 concrete vaut. Capacity of the tank is $2250 \mathrm{gal}(8520 \mathrm{~L})$.

Function of the SWMU: This tank [and W-19 (SWMU 1.56a)] were inetalled for the purpoee of colvecting UW solutions from Bulling 3505. After closure of the Motal Recovery Fecilly in 1860, the tanks were used for a period of 1-2 years by the Fission Product Development Laboratory for $L W$ collection.

Ostes of Operation: The Metal Recovery Facility was constructed in 1951 and commiesioned in 1952. The tanks collected wastes from 1952 until the early 1860s, when they were removed from service.

Weste Characteristics: The tanks are reporiecly empty but they remain internally contaminated. Prit mary wastes handled by the Metal Recovery Facifity contained Sr-80, Co-137, Fu-238, PU-239, and Pu-240. In addition, wastes from the Fission Product Development Laboratery contained sionificant quentitios of Co-144 and Pm-147.

Reloese Data: There have been no reported leaks or releases. 
EPA H.A.1 DATA SUMMARY SHEET

WAG DO Number: 5 WAG Namo: Solld Waste Storago Area (SWSA) 5

SWMU ID Number: 5.11 SWMU Namo: Septic Tank-Building 7831

Location of Unit. Septic tank is located within the boundary of SWSA 5. ORAL grid coordinatee are $N$ 18,750 and $E 31,140$.

Genord Dimensions and Capecities: Tank is a concrete structure with a capacity of 500 gal (1880 L).

Function of the SWMU: Septic tank is used to collect and dispose of raw domeetic sewage from the Waste Compactor Building (7831).

Dates of Operation: hotallation date is not known; tank bs still in service.

Waste Cheracteristica: Only domeetic sewepe from Buiding 7831 hes been collected/stored in the tank. No hazardous or radioective wastes have been added to the syotem.

Rabeses Deta: There have been no reported leaks or rebeases. 
EPA H.A.1 DATA SUMMARY SHEST

WAG ID Number: 5

WAG Namo: Solid Waste Storage Area (SWSA) 5

SWMU DD Number: 5.12

SWMU Name: Septic Tank - Bullding 7860

Location of Unit: The septic tank is located in the enuthwest corner of WAG 5 and serves the Now Hydrotracture Factlty (7860). The OPNL grid coordinates are $N$ 16,537 and E 28,250.

General Dimensions and Capacitios: Tank is a concrete structure with a capactly of 500 gal (1880 L).

Function of the SWMU: Septic tank is used to collect and dispose of raw domestic sewage from the Now Hydrofracture Facility (7880).

Dates of Operation: Septic tank was installod in 1978 and to still in wee (9 years).

Waste Characteristics: Only domestic sewage from Building 7860 has been collocted/stored in the tank. No hazardous or rediosctive wastes have been added to the system.

Release Data: There have been no reported leaks or releases. 


\section{EPA II.A.1 DATA SUMMARY SHEET}

WAG D Number: 5

WAG Name: Solld Waste Storage Aree (SWSA) 5

SWMU 10 Number: 5.13

SWMUU Namo: Septic Tank - Building 7853

Location of Unit: The septic tank is located in the souttmweet corner of SWSA 5 and serves the Old Hydrotracture Facillty (Blog. 7853). The OPNL grid coordinatee are $N$ 17,130 and E 28,710.

General Dimensions and Capecitice: Tank is a concrete structure with a capectity of 750 gal $(2840 \mathrm{~L})$.

Function of the SWMU: Septic tank is used to collect and dispose of raw domeetic sewage from Bullding 7853.

Dates of Operation: Septic tank was inotalled in 1988 and is currently not in service.

Wasto Characteristica: Only domeatic sowage from Bullding 7853 has been collectod/stored in the tank. No hazardous or radioactive wastes have been added to the system.

Reloasen Data: There have been no reported leaks or releasec. 
EPA H.A.1 DATA SUMMARY SHEET

WAG ID Number: 7

SWMU ID Number: $7.4 \mathrm{~d}$
WAG Name: LLW PHe and Trenches Ares

SWMU Name: Leak in Tranater Line from Decontamination Facility (7819) to Pit 1 (7805)

Location of Unit: The leak atte is located $60 \mathrm{ft}(18.3 \mathrm{~m})$ south of Lagoon Road and $35 \mathrm{ft}(10.7 \mathrm{~m})$ weet of the access road to the Pits and Trenches Area. The ORNL grid coordinates are N 18,020 and E 26,940 .

General Dimensions and Capactives: The total area of contamination is reported to encompase about $925 \mathrm{t}^{2}$ (86 m2).

Function of the SWMU: A Gin. (15-cm) drain ine served to transter decontamination waste solutions from the Decontamination Facilty (Bidg. 7819, SWMU 7.1) to LW PH 1 (Bldg. 7805, SWMU 7.5).

Dates of Operation: The date of the leak is not known; however, the faciily was operated from the earty $1960 \mathrm{~s}$ through the earty 1970 s.

Waste Characteristics: A preliminary environmental survoy for Bldo. 7818 found Co-137 to be the dominant radionuclide in solls surrounding the faclity. It is believed that the wastes from Bidg. 7819 would consist of corrosive wastes (1.e., acids) and radionuclides associated with the equipment being decontaminated.

Release Data: The dominant detectable radionuctide was Cs-137. There may have been some corrosive wastes and additional radionuclides that were associated with the decontamination procedures. 
EPA I.A. 1 DATA SUMMARY SHEET

WAG ID Number: 7

WAG Name: LLW Pits and Trenches Area

SWMU D Number: 7.11

SWMU Nams: Septic Tank-Builing 7819

Location of Unit: The septic tank is located north of SWSA 4 at the intersection of Lagoon Road and the roed leading to the LLW Pits and Trenches. The ORNL grid coordinatee are N 19,320 and E 28,980.

General Dimensions and Capecitioa: Tank is a concrete structure with a capactly of $540 \mathrm{gal}(2040 \mathrm{~L})$.

Function of the SWMU: Septic tank is used to collect and dispose of raw domeetic sowage from Bulloting 7819 (Decontamination Facility).

Dates of Operation: Installation date is not known; tank is not in serrice.

Waste Characteristics: Only domestic sewage from Building 7819 has been collocted/stored in the tank. No hazardous or radioactive wastes have been added to the system.

Release Data: There have been no reported leaks or releases. 
EPA H.A.1 DATA SUMMARY SHEET

WAG ID Number: 8

SWMU DD Number: 8.11
WAG Name: Melton Valley Area

SWMU Name: Septic Tank-Building 7503

Location of Unit: The septic tank is located adjacent to the Molten Salt Reactor Facillty (Building 7503). The ORNL grid coordinates are $N$ 18,670 and E 32,490.

General Dimensions and Capactios: Tank is a concrete structure with a capactty of 1500 gal (5880 L).

Function of the SWMU: Septic tank is used to collect and dispose of raw domestic sewage from Buildins 7503.

Dates of Operation: Septic tank was installed in 1951 and is still in use (36 years).

Waste Characteristics: Only domestic sewage from Building 7503 has been collected/ atored in the tank. No hazardous or radioactive wastes have been added to the system.

Pelease Data: There have been no reported leaks or releases. 
EPA II.A.1 DATA SUMMARY SHEET

WAG ID Number: 16

SWMU ID Number: 16.3
WAG Name: Hoalth Physics Research Reactor (HPFR) Area

SWMU Namo: Buried Scrap Motal Area

Location of Unit: The site is located south of Bulding 7710 at the point where the road to the reactor (Bidg. 7709) turne woot. The ORNL, grid coordinates are $N$ 11,150 and E 36,250.

Ceneral Dimensions and Capacities: The size of the burial trench is undetermined. It is esthmated that the total area is approximately $40 \mathrm{ft}$ by $50 \mathrm{ft}(12.2 \mathrm{~m}$ by $15.2 \mathrm{~m})$.

Function of the SWMU: The area was used as a waste pib prior to burial in place.

Dates of Operation: Matertal was stored on the surface from the earty 1980 s to the earty 1880 when some of the material was removed to other areas and the remainder was buried in place.

Waste Characteristica: The known materials buried inctuded a container ( 4 tt by 3 it $[1.2 \mathrm{~m}$ by $0.9 \mathrm{mD}$ of polyethylene beads and a collection of Japanese building construction materials. These wero uncontaminated materials which originated from the Novada Teat Site. Three sealod raciation sources, ceaiurn and cobalt, were stored in the area but were removed to SWSA 6 in 1983.

Relcase Data: There have been no reported releeses. 
EPA U.A. 1 DATA SUMMARY SHEET

WAG ID Number: 16

SWMU DD Number: 16.4
WAG Name: Hoatth Physics Research

Reactor (HPRR) Area

S'WMU Name: Septic Tank-Bullding 7709

Location of Unit: The septic tank is located west of the DOSAR Reactor Bullding (7709) in the HPAR Area. The OANL grid coordinates are $N 12,310$ and E 35,840.

General Dimensions and Capacities: Tank ts a concrete structure with a capactly of $600 \mathrm{gal}(1880 \mathrm{~L})$.

Function of the SWMU: Septic tank to used to collect and dispose of raw domestic sewage from Bulleing 7709.

Dates of Operation: Septic tank was installed in 1982 and is still in use (25 years).

Wasto Characteristics: Only domestic sewage from Bulliding 7700 has been collected/stored in the tank. No hazardous or radioactive wastes have been added to the syatem.

Release Data: There have been no reported leaks or releases. 


\section{EPA II.A.1 DATA SUMMARY SHEET}

WAG ID Number: 10

SWMU ID Number: 16.5
WAG Nams: Hoatth Physics Research Reactor (HPRR) Area

Location of Unit: The septic tank is located at the DOSAR Facility Control Bullding (77 10) in the HPRP Area. The ORNL orid coordinates are N 13,320 and E 36,450.

General Dimensions anci Capacities: Tank is a concrete structure with a capactly of $1200 \mathrm{gal}(4340 \mathrm{~L})$.

Function of the SWMU: Septic tank is used to collect and dispose of raw domeetic sewage from the DOSAR Facillty.

Dates of Operation: Septic tank was installed in 1982 and is stth in use (25 years).

Wasto Characteristics: Only domestic sewace from Bullding 7710 has been collected/stored in the tank. No hazardous or radibactive wastes have been added to the system.

Redease Data: There have been no reported leaks or releases. 
EPA II.A.1 DATA SUMMARY SHEET

WAG ID Number: 10

WAQ Name: Hazardous Wasto Treatment and Storage' Facillitios

SWMU ID Number: 18.7

SWMU Name: Soll mibction of Radbactive

Cas

Location of Untt: The site to located in the same general area as SWMU: 19.6 and 19.6 (the Leaking Gas Cylinder and Reactive Chemical Disposal Areas, respectivety). ORNL grid coordinates are $N$ 17,850 and $E 39,750$.

General Dimenaions and Capactilies: The area is fenced and mesucures about 75 by 160 tt (23 by 46 m).

Function of the SWMU: The original descilption of this unit was based on verbal information and is incorrect. More detalled investigation indicates that this sitte (known as the "Sandla Site") was used to pertorm heater tests in the shave to obtain thermal information for wese in the hiohtovel waste repository program. No radingctivity or chemical wastes were involved at the site. No records extat to supoest any gas injections at this atte.

Dates of Operation: The site was constructed and operated Uuring the period 1976-1977.

Weste Characteristics: No wastes (radibactive or hazardous chemical) were involved in the studies at this site.

Release Data: No releases have occurred. Equipment has been removed from the site. Site is currently used for SWMUs 19.5 and 19.6 (se0 RFA). 
EPA II.A.1 DATA SUMMARY SHEET

WAQ 10 Number: 19

SWMU ID Number: 19.8
WAG Namm: Hezardous Westo Treatment and Storage Facillice

SWMU Name: Exploeive and Shook. Senattive Wasto Detonation

Location of Unit: The tacility lo located about $200 \mathrm{Ht}(81 \mathrm{~m})$ northweet of the Hazardous Waste Management Area (located on Hoalth Physics Research Reactor Accees Road approximately $1 / 2$ mile $[0.8 \mathrm{~km}]$ south of Metton Valloy Ditvo). The ORML grid coordinutes are N 16,650 and E 37,000.

General Dimensions and Capactiles: The site consiste of two exploatve material storace magazinee, a detonation trench, and a control sito. The siorage magaztnee are separated by a dit berm and are located on concrete pads. The entre structure lo surrounded by a securtty fence. The detonation trench to $10 \mathrm{ft}$ long, $6 \mathrm{ft}$ widh, and $4 \mathrm{ft}$ deep $(3.0 \mathrm{~m} \times 1.5 \mathrm{~m} \times 1.2 \mathrm{~m})$ and lo esurrounded by a securtty fence.

Finction of the SiMMU: The tunction of the factity lo to provide a sate, effective, and environmentally acceptabio method for the dispoesel of explosive and shock-seneittive chemicala.

Dates of Operation: This fecillty has not been used as of August, 1987. This SWMU will replece the detonation trench in SWSA 6 that had been used for a number of years (SWMU 8.3).

Wasto Characteristics: Examples of chemicals that will bo detonatest inctude plectic acid, phosphorus, mydrogen peroxide, ammonkum nitrate, and other shock-sensittve chernicals.

Raibase Data: Chemicaid, exploaivea, and, in most inotances, their containers, are vaportzed or putverized in the explosion. Any fragments that remain after the explosion are removed; hence no releasea will occur. 
EPA H.A.1 DATA SUMMAAY BHEET

SWMU D Number: OS.1

SWMU Narno: Abandoned Bum PH

Location of Untt: The alte is located north of Bethel Valloy Road acroses from the 7000 area (WAG 17, ORNL Services Area) on Chestnut Ridoe Road. The Sanitary Waste Compactor (Bldo. 0954) is currently located on the atte. ORNL grid coordinates are $N$ 23,100 and E 37,850.

General Dimensions and Cepactios: No records of the exact dimenaions of this faclity extat.

Function of the SWMU: During the carty operation of the Laboratory, this site was used for burning of combustible trash. The pit in which the burning took place has been backfilled. The Sanitary Waste Compactor to currently located at this site.

Dates of Operation: Belleved to have begun operation at or near the time of clocurs of SWSA 4 about 1958. Operations ceased in 1868 when the compactor was inotalied at the site.

Waste Characteriatics: Wood, refuse, and combustible construction debrits were burned in the pht. No records exist as to the exact nature of the material burned. It has been reported, however, that on at least two occasions laundry materials contaminated with very-towtovel radioactivity were burned in the pht. Materials stored on the surtace in this area may have been buried in the area immediately north of the compactor.

Release Data: There is no historical information on releases of hazardous or radioactive materiats. Results from sampling surveys reported in Sect. 3.7 of this Addendum angoest elevated levels of Cd, $\mathrm{Cu}, \mathrm{Pb}$, and $\mathrm{Zn}$. Cesium-137 activity was observed at 5-15 times background. 
EPA II.A.1 DATA SUMMARY SHEET

SWMU ID Number: 0 S.2

SWMU Name: Septic Tank - Building 0907

Location of Unit. The septic tank is located east of Bullding 0907, which is north of Bethel Valloy Road about 2-3 miks from the Main Plant Area.

General Dimensions and Capacithes: Tank is a concrete structure with a capactly of $550 \mathrm{gal}(2080 \mathrm{~L})$.

Function of the SWMU: Septic tank is used to collect and dispose of raw domestio sowage from Bulloting 0907.

Dates of Operation: Septle tank was installed in 1968 and is still in use (29 years).

Waste Characteriattics: Onty domeetic sewrage from Bulding 0907 has been collected/stored in the tank. No hazardous or radioactive wastes have been added to the system.

Palease Data: There have been no reported leaks or releases. 
APPENDIX B

SUMMARY SHEETS-ENVIRONMENTAL RESEARCH AREAS 


\section{APPENDIX B}

\section{ENVLRONMENTAL RESEARCH AREAS}

During the past 25 years, a number of field studies have been performed in areas surrounding ORNL related to the cycling and fate of radionuclides in terrestrial and aquatic ecosystems (Taylor 1986, Saylor 1986). Several of these studies were related to obtaining a better understanding of the fate of radionuclides resulting from fallout from nuclear detonations. Although these sites do not fall under the guidelines that identify SWMUs, and as a result are not to be considered a part of the RFA, ORNL has elected to include summary information (using the same format followed in developing the SWMU Summary Sheets in the RFA and this Addendum) on these sites so that a complete picture of all currently identified contaminated areas can be presented. Table B.1 summarizes ORNL's recommendations regarding future actions for these 34 sites.

The locations of these areas relative to ORNL are illustrated in Figs. B.1 through B.4. Many of the areas are a considerable distance from the ORNL Main Plant Area and have not been assigned ORNL grid coordinates. Also, the exact location of some of the sites is only vaguely reported. As a result, in this Addendum and the supporting documents, these sites are located by azimuths and distances $\mathrm{fr}^{\prime}, \mathrm{m}$ known road intersections. 


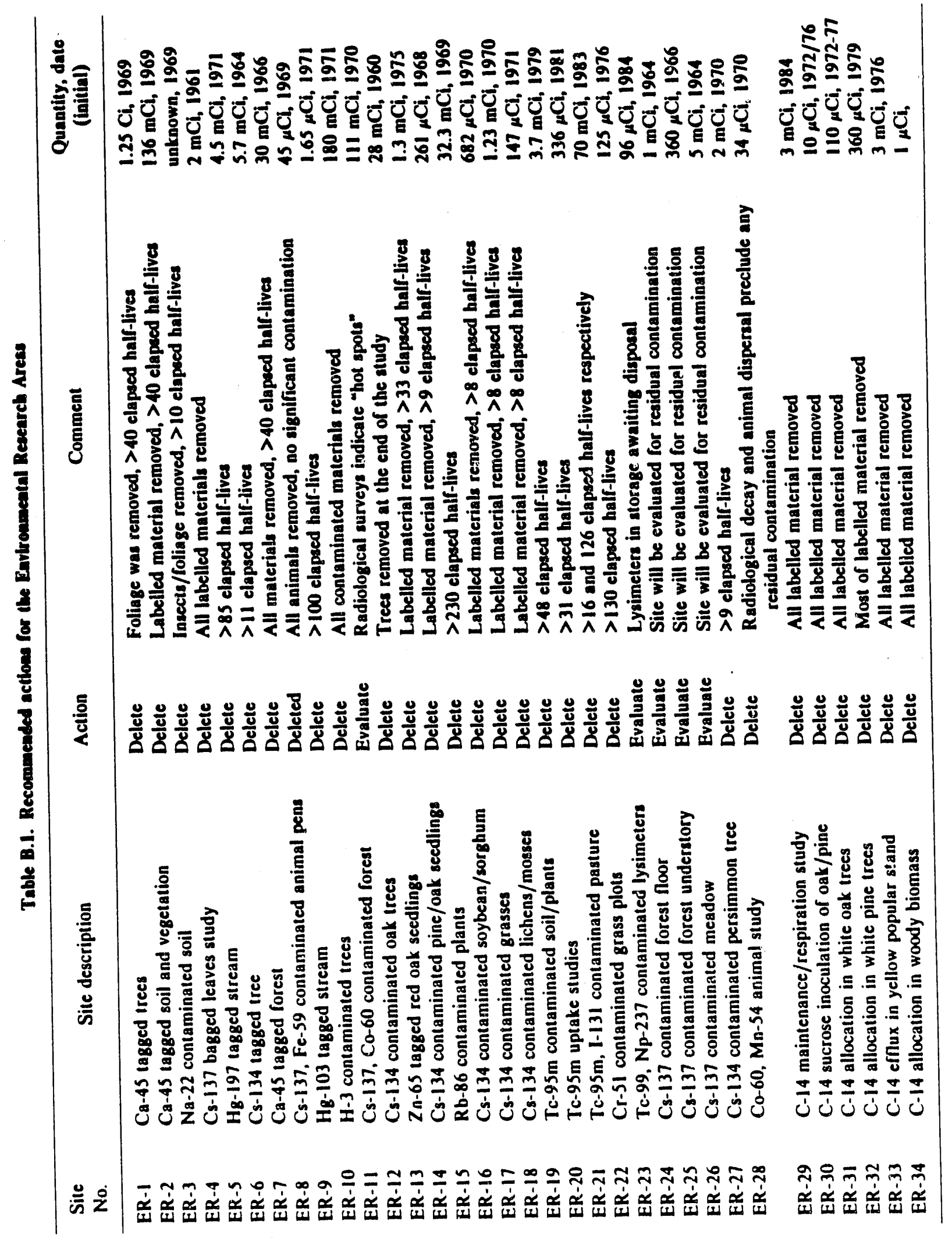




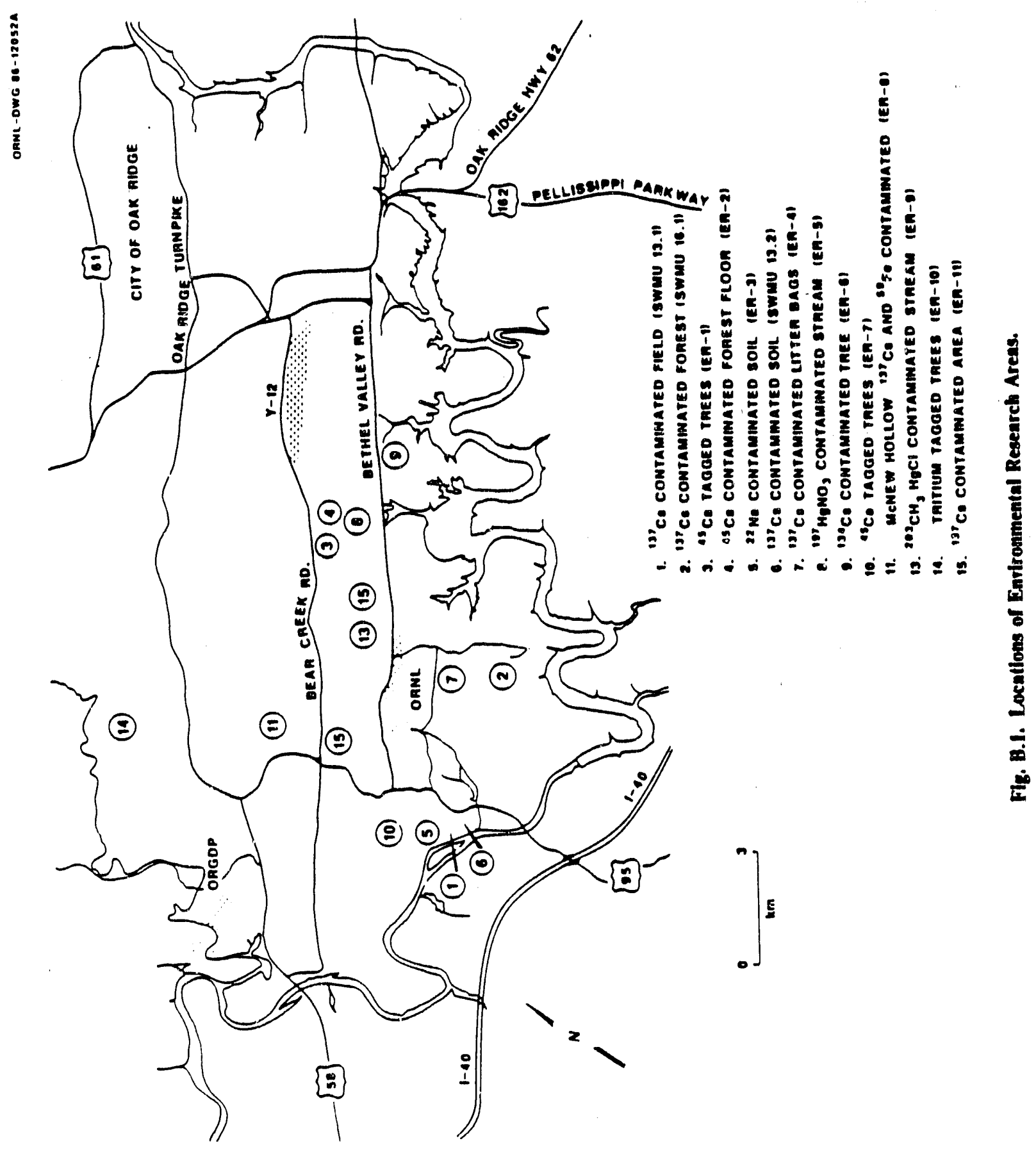




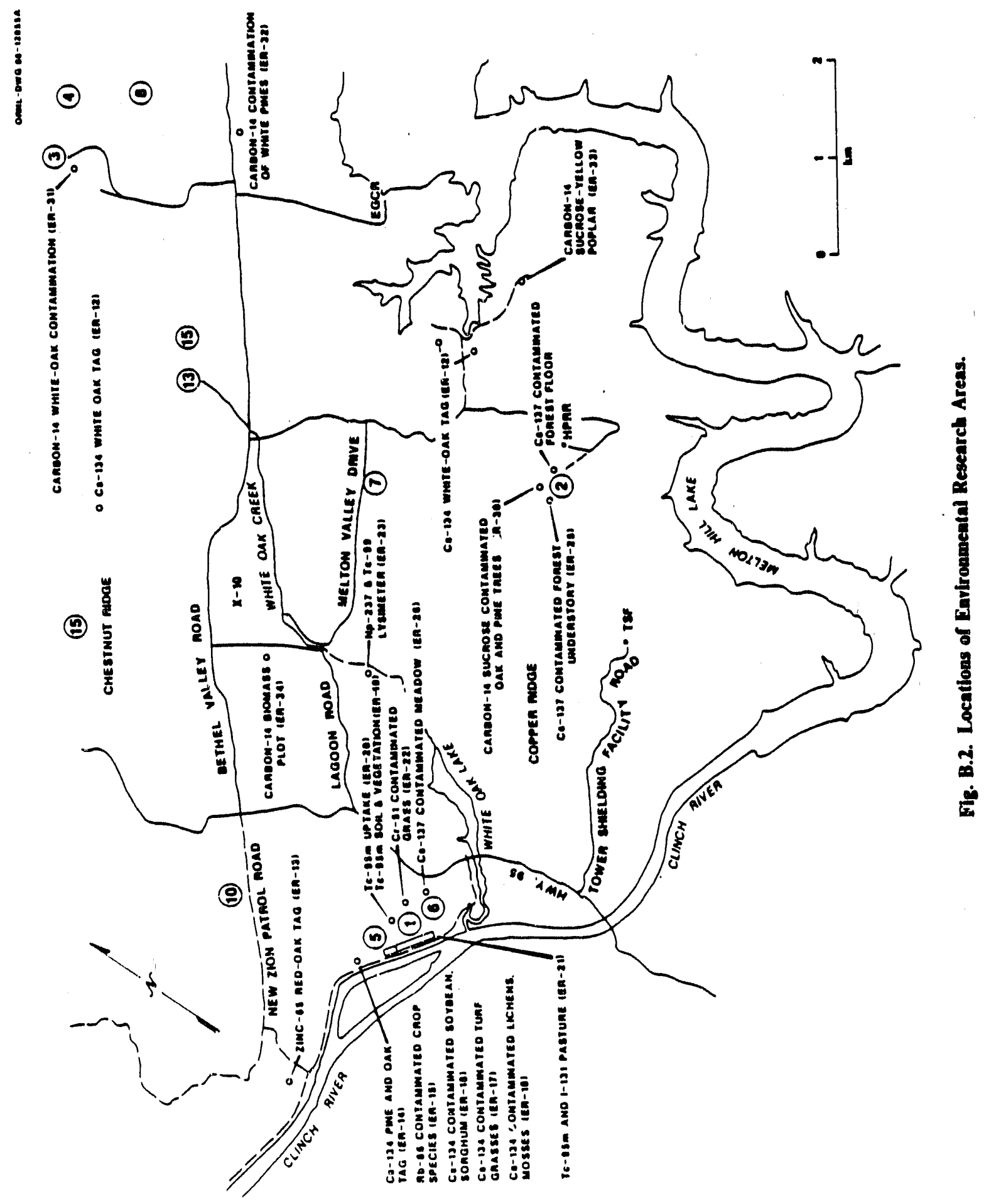




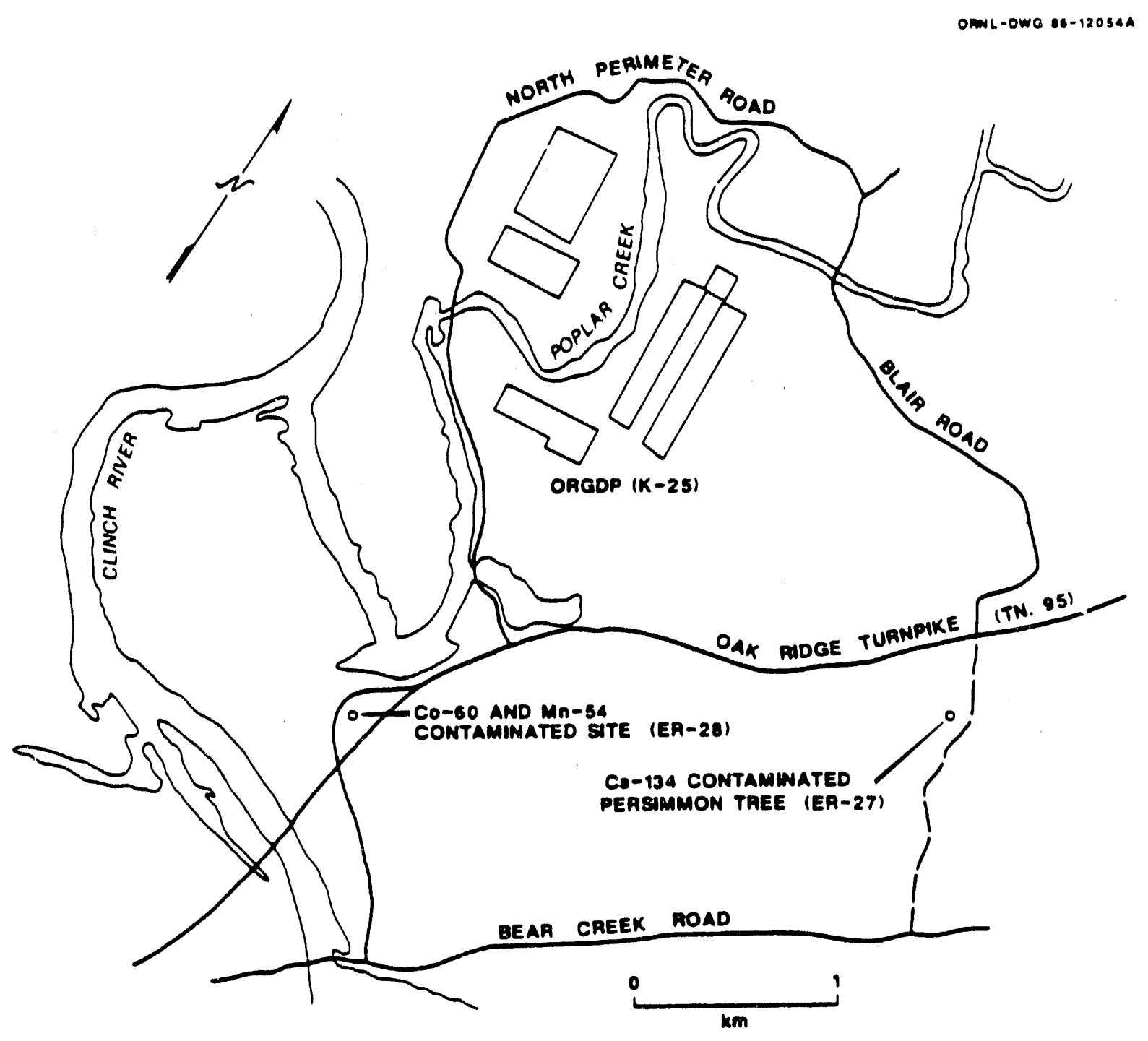

Fig. B.3. Locations of Envirombental Research Areas. 
0
0
0
0
1
0
0
0
0
0
1
2
0
0

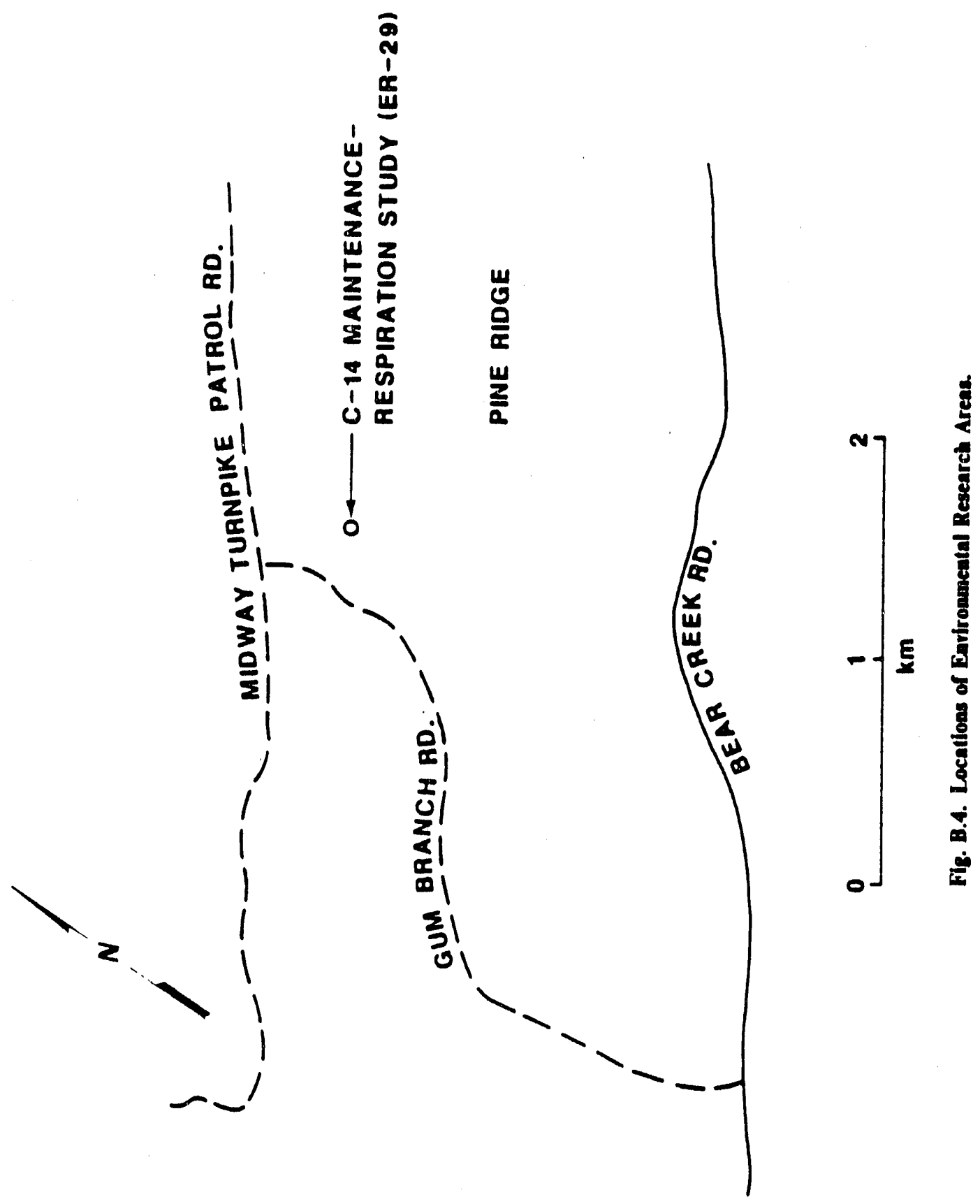




\section{REFERENCES FOR APPENDIX B}

Saylor, R. E. 1986. A summary of ORNL Remedial Action Program data and identification of data deficiencies for low-level waste leak sites, environmental research areas, and hazardous waste sites. ORNL/RAP/LTR-86/26. Oak Ridge National Laboratory, Oak Ridge, Tennessee.

Tayior, F. G. 1986. Inventory of ORNL remedial action sites: 6. environmental research areas. ORNL/RAP/LTR-86/18. Oak Ridge National Laboratory, Oak Ridge, Tennessee. 
EPA II.A.1 DATA SUMMAPY SHEET

ID Number: ER-1

Namo: Ca-46 Tagged Treee

Location of Unit: Site ER-1 ls located on Walker Branch watorshed (Chestnut Ridge), a dlatance of 2 miles $(3.2 \mathrm{~km})$ on an azimuth of N $24 \mathrm{E}$ from the intersection of Bethel Valley Road and Melton Valloy Access Roed.

General Dlmensions and Capacitios: The contaminated area was probably less than 1.2 acres (0.5 ha).

Finction of the Unit: Several red maple trees were inoculated with Ca-45, which was allowed to move in the transpiration stream throughout the treo. Objective was to produce Ca-46 containing leaves for use in experiments at ER-2.

Dates of Operation: The lsotope was infected into the trees on June 7, 1969. Leaves were removed and procesesed prior to December 20, 1969 (see ER-2).

Waste Characteristica: The maples were injected with $1.25 \mathrm{Cl}$ of Ca-45 (halffite $185 \mathrm{~d}$ ) in solution.

Relases Data: Following several days posttaging, all follage from the treee was removed, processed, and prepared for use at Site ER-2. Due to the short halftife, all of the remaining Ca-46 at ER-1 will have decayed to nondetectablo levels. 


\section{EPA H.A. 9 DATA SUMMARY SHEET}

D Number: ER-2

Nama: Ca-45 Tacoed Soll and Vecotation

Location of Unit: SHte ER-2 is located in an oak/hickory foreat on the Walker Branch waterahed (Cheatnut Aidge), a distance of 2.2 miles $(3.6 \mathrm{~km})$ on an aztrmuth of N 31 E from the intervection of Bethel Valley Road and Metton Valley Access Road.

Gameral Dimensions and Capactios: Approximately $160 \mathrm{ft}^{2}\left(15 \mathrm{~m}^{2}\right)$ of land aurtace was included in tho experimental plot.

Function of the Unit: The stte was contaminated with $\mathrm{Can} 45$ labeled follace to determine the movement of the liotope into soll and solf-water solution. The method of contamination was to introduce maple leaves containing Ca-45 (from ER-1) to the soll at ER-2. A quanttly of contaminated leaves were placed in meah bags and were dispersed at the atte.

Dates of Operation: The radioactivity $(\mathrm{Ca}-45)$ was introduced on December 20, 1889. The duration of the study was 72 woeks.

Wasty Characteristics: It is reported that $136 \mathrm{mCl}$ of Ca-45 (half-tite $165 \mathrm{~d}$ ) was contained in the baves.

Reloase Data: At the termination of the experinent, all leaves contained in the meah begs were removed and disposed. Because the hali-life of $\mathrm{Ca}-45$ is only $185 \mathrm{~d}$, no detectable radbactivity from the experiment is present at the site. 


\section{EPA II.A.1 DATA SUMMAFY SHEET}

ID Number: ER-3

Nama: Na-22 Contaminated Soll

Location of Unit: Site ER-3 is in the vicinity of the 0800 stea. It to located off Jones leland Patrol Road near the Cinch River, a distance of 1.1 milos $(1.6 \mathrm{~km})$ on an azimuth of $810 \mathrm{~W}$ from the interesction of Bethel Valley Road and State Hothway 96.

General Dimonsions and Ceppectios: Area of the sito wes 1.2 acres (0.5 ha).

Function of the Unit: Activities at this site span several years and lnvotved Ca-47, K-42, and Na-22. It is belloved that isotopes were applibed to vecetation in the laboratory and the contarninated vegetation fod to grasehoppers and crickets housed in cages in the field.

Dates of Operation: The exact dates of lsotope contamination are unknown; however, activities cocurred during $1968-1969$ at ER-3.

Waste Characterdatics: Follage was contaminated with an uniknown quantity of Ca-47, K-42, and Na-22. Sodum was the most sionificant lsotope because of the lonoer half-life (2.62 years).

Ralease Data: Although the exact arnounts of radionuctides involved are unienown, almoot 10 half theo have lapeed since the tracer was introduced. No records exiot to indicate that contaminated animal reat duas were removed; however, the insects and follage were removed from the sto. It is doubthul that detectable radionuctides remain at the aite. 
EPA H.A.1 DATA SUMMARY SHEET

D Number: ERA

Name: Os-137 Bagoed Leaves Study

Location of Unit: Site ER-4 ts located south of Melton Valloy Drive, distance of 0.8 milles $(1.3 \mathrm{~km})$ on an azionuth of E $83 \mathrm{~S}$ trom the intersection of Bether Valley Road and Melton Valloy Acceses Road.

General Dinensions and Capacties: Intormation on the aze of the contaminated area is unknown.

Function of the Untt: ER-4 was utllized as a baoped leaves study area to determine differences in lootope solubility from leaves under natural condtitions. Leaves were contaminated with C.-137 and Co-60 in mesh bags within a phre oak forest. The bagoed leaves were perlodically removed for analyals during a one-year period.

Dates of Operation: The initial date of contamination cocurred at an unknown time during earty 1861 and the stte was uttllzed for about one year.

Waste Charactertetics: Follages and soll were contaminated with approximately 2 mCl equally divided between C0-137 and CO-60. It has also been reported that some bags containing loaves contaminated with Rur-106 and Sr-80 were placed at the site. The quantity of radionucildes invotved ts not known.

Release Data: More than 25 years have elapsed (0.8 halfflfe for the C. 137 and 4.8 half thee for the $\mathrm{CO}_{-60}$ ) since the mesh bags were first placed in the field. If all of the bags and follage contents had remained at the site approximately $0.55 \mathrm{mCl}$ and $36 \mu \mathrm{Cl}$ would remain for the $\mathrm{Co-137}$ and $\mathrm{Co-60}$, respectively. Since all experimental materials were removed at the completion of the study, no detectable contamination remains at the site. 
EPA II.A.1 DATA SUMMARY SHEET

D Number: ER-6

Namo: Ho-187 Tagoed Stroam

Location of Unit: Site EA-5 lo located 2.2 miles $(3.6 \mathrm{~km})$ on an azimuth of N 41 E from the intersection of Bethel Valloy Road and Metton Valloy Acceses Roed. The sito is downatream from the Walker Branch waterahed weirs.

General Dimensions and Cepactibes: The study area Invotves a 330-ft $(100-\mathrm{m})$ section of stream in Waker Branch.

Function of the Unit: A section of Walker Branch was tagoed with radioacitue mercuric nitrate [187 $\left.\mathrm{HO}\left(\mathrm{N}_{0} 3\right)_{2}\right]$ to determine the fate of that mercury compound in a natural stream ecosystem. The sam ple matrix consioted of water, fiah, watereress, periphyton, and sedimente.

Dates of Operattion: The radionctivity was introduced into Walker Branch on October 5, 1971.

Weste Charactertatica: $4.48 \mathrm{mCl}$ of mercuric nitrate (Ho-197; hatf the $65 \mathrm{~h})$ was appliod to the stream.

Redeace Data: At a streamflow rate of $347.8 \mathrm{~L} / \mathrm{min}$, $75 \%$ of the mercury lootope was retained in the first $300 \mathrm{Ht}(100 \mathrm{~m})$ of the stream. Because of the botope's short halfthe, no detectable Ho-187 remains at the stte. 
EPA H.A.I DATA SUMMARY SHEET

D Number: ER-

Name: C. 134 Tagoed Tree

Location of Unit: SHte ER-6 is located 2.2 miles $(4.5 \mathrm{~km})$ on an azimuth of N 55 E from the intersection of Bethet Valloy Road and Melton Valloy Access Road.

General Dimensions and Capactios: Approximately $1100 \mathrm{t}^{2}\left(100 \mathrm{~m}^{2}\right)$ of area containing a red cadar tree was involved.

Function of the Unit: This study was decigned to determine the uptake and transfor of Co-134 through metamorphosis of the bagworm moth. A red cedar tree wes hoculated with Co-134 and the insects were contained in cages suspended by wires near the canopy of the hoet tree.

Dates of Operation: The red cedar tree wes hooulated with Cs-134 on August 15, 1864.

Waste Characteristics: $5.68 \mathrm{mCl}$ of Co-134 (haff the 2.05 years) was injocted into the tree.

Release Data: Approximately 11 halftives have lapeed since the tree wes contaminated, potentially leaving a maximum of $3.4 \mu \mathrm{Cl}$ of radioactivity. However, this quantity has been further dituted by natural processes, weathering, leaf transport, and soll baching. 
EPA II.A.1 DATA SUMMARY SHEET

D Number: EAT

\author{
Name: Ca-16 Tagoed Foreet
}

Location of Unit. Site ER7 is located 0.45 mive $(0.7 \mathrm{~km})$ on an aximuth of W $25 \mathrm{~S}$ from the intersection of Bethel Valley Roed and State Hithway 95 in Roans County.

General Dimenaions and Capecitiea: The extent of the contamination is unknown but is assumed to be lees then 2.47 scres (1 ha).

Finction of the Unit: The purpose of the study was to document the sccumulation of calcium by various plant organs and to determine the rate of calcium cycling in the treo-ecil syotem. Twelve dogwood trees were inoculated with amounts of isotope ranoing trom 0.67 to $2.51 \mathrm{mCl}$ per tree.

Dates of Operation: The dogwood trese were inocilated with the Ca-15 (hakr-fife 185 d) on May 4, 1868.

Waste Charactoristicas: The total amoum of isotope used in this study was approximately $30 \mathrm{mC}$. Samr pline of wood, foliace, and plant organs (1.e., flowers, etc.) wes conducted.

Reloses Data: Because all experimental materiats were removed at the termination of the study and more than 40 half tives have lepeed since the site was contarninated, no detectable Ca-45 should be present. 
EPA II.A.1 DATA SUMMARY SHEET

DD Number: ER-8

Name: Co-137, Fo-59 Contaminated

Animal Pens (McNow Hollow)

Location of Unit: Site ER-8 is bocated 2.1 miles $(3.4 \mathrm{~km})$ on an azimuth of $N 18$ W from the intersection of Bethel Valloy Road and State Hiotwway 95 in an area called MoNlow Hollow.

General Dimenaions and Capacitios: Four pens (each $33 \mathrm{Ht}$ by $33 \mathrm{tt}$ [10 $\mathrm{m}$ by $10 \mathrm{mD}$ were utillzed. The extent of contarrination is about $4300 \mathrm{tt}^{3}\left(400 \mathrm{~m}^{2}\right)$.

Function of the Unit: This field study was conducted to determine the elimination of Ce-137 and Fo-59 by wild amall rodents. Periodically, the animalo were fivo-trapped and taken to the laboratory for radiolosical analyeis.

Dates of Operation: Cotton rats, contaminated using a dual botope rectrique, were rebesed into the pens in January 1869.

Waste Characteristics: The cottion rats were contarninated by injection with CO-137 (halfifte 30 yeara) and Fo-59 (halififte $45.6 \mathrm{~d}$ ). A total of $32 \mu \mathrm{Ci}$ of $\mathrm{Co}-137$ and $12.8 \mu \mathrm{Ci}$ of Fo-59 was utilized.

Reloase Data: All animats in the pens were removed at the end of the experiment. Correcting for radiological decay, approximately $21 \mu \mathrm{Cl}$ of Co-137 would remain at the site if all of the isotope remained there. tron-69 would have decayed to nondetectable levels. No detectable radioactivity remains at the site. 
EPA II.A.1 DATA SUMMARY SHEET

D Number: ERP

Namo: Ho-203 Tagged Stream

Location of Unit: Site ER-9 is a portion of White Oak Creek located in Bethel Valloy 0.5 milo $(0.8 \mathrm{~km})$ on an azimuth of $N 12$ E from the junction of Bethel Valley Roed and Melton Valloy Access Roed.

Gersis Dimensions and Capacitios: The contaminated area encompasses $330 \mathrm{ft}(100 \mathrm{~m})$ of stream bonoth.

Function of the Unit. This site was ution to clarify the fate of mothylmercury $\left(\mathrm{CH}_{3}{ }^{200} \mathrm{HoCl}\right)$ in a natural stream ecosystem.

Dates of Operation: The methytmercury was introduced into the strean on September 1, 1971.

Wasto Characteristics: Water, fish, plants, and sediments were contaminated with $1.65 \mathrm{mCl}$ of methyt mercury containing Ho-203 (halftito 46.9 d).

Release Data: At a streamilow of $325.6 \mathrm{~L} / \mathrm{min}, 81 \%$ of the radioisotope was retained in the first $330 \mathrm{ft}$ $(100 \mathrm{~m})$ below the point of release. No detectable radionuctides are present at the site. 


\section{EPA U.A.1 DATA SUMMARY SHEET}

ID Number: ER-10

Namo: $H-3$ Contaminated Trees

Location of Unit: Site ER. 10 is located 1.6 miles $(2.6 \mathrm{~km})$ on an azimuth of W 8 S from the intersection of the East Ridge Patrol Road and the Oak Ridoe Tumpike on Blackoak Ridoe adjacent to the East Ridoe Patrol Road.

General Dimensions and Capacities: The aree involved in the study was about 0.6 acre (0.25 ha). The area inctuded two yellow poplar trees, one hickory tree, and a $43-\mathrm{tt}^{2}\left(4-\mathrm{m}^{2}\right)$ soll plot.

Function of the Unit: This ridgetop site was utillzed in a plit study to investioate the fealibity of uaing tritiated water to measure rates of transpiration of deciduous tree species (yellow poplar and hickory) under field conditions.

Dates of Operation: The tritium was introduced into the trees on May 16, 1971.

Waste Characteristics: Approximatcly $180 \mathrm{mCl}$ of tritiated water (half thite 12.26 years) was injocted into the trees.

Release Data: Correcting for radiological decay, approximately $77 \mu \mathrm{Cl}$ of trithm would be the maximum amount present at the site; however, following completion of the study all materials were removed from the site. Because tritium is mobile, it is doubtful that any residual tritium could be detected at the site. 


\section{EPA II.A.1 DATA SUMMARY SHEET}

DO Number: ER-11

Name: Co-137, Co-60 Contaminated

Foreat Area

Location of Unit: Site ER-11 contained two radiolsotope treatment plots on Cheotnut Ridos. Ore plot was located 0.8 mile $(1.35 \mathrm{~km})$ on an aximuth of $S 84 \mathrm{~W}$ from Bidg. 2001 at OFNL, and the other 1.55 miles $(2.51 \mathrm{~km})$ on an azimuth of N 49 E. A third plot (location undefined) served as a control.

Genoral Dimensions and Capacities: The treatmemt plote were 4.85 acres (4.98 ha) each. A total of about 9.7 acres (4 ha) was involved in the study.

Function of the Unit: The objective of the study was to utilize the radiobotopes to determine annual and seasonal consumption rates of white pine seeds by small forest mammals. Animals in the study plote were live-trapped, isotopic body burdens determined in the laboratory, and the animala returned to the foreat at the point of trapping.

Dates of Operation: Eech of the two study areas received applications of contaminated secds (tagoed with Co-137 and Co-60) between Juty 31, 1989 and September 3, 1970.

Waste Characteristica: The total amount of isotope in the applied seede was approsinnatety 5.8 mCl of C8-137 (halfitite 30 years) and $49.7 \mathrm{mCl}$ of $\mathrm{Co} 60$ (halifife 5.2 years) for each plot.

Pevase Data: As a reaut of the long-term study, the radibactive materiabs were constanthy being removed from the site by feeding, but a fraction was being returned through body-limination processes. Correcting for radiological decay, approximately $4 \mathrm{mCl}$ of $\mathrm{Co}-137$ and $5.5 \mathrm{mCl}$ of Co-60 would be the maximum amount of activity that would remain at the site if none were removed. These quantitios would be further diluted by feed (food) placement by the reaident animala, in excrement of animale meandering from the site, and scavenging by animals passing through the area. Field radiological surveys indicate that thero may be some hot spots" (1-2 $\mathrm{mA} / \mathrm{h})$ present in the plots. 
EPA II.A.1 DATA SUMMARY SHEET

1D Number: ER-12

Name: Co-134 Contaminated Oak Trees

Location of Unit: Site ER-12 consists of four subaites, each selected to represent a different soil type. Two of the sites (Landisburg and Fullerton) are on the north slope of Chestrut Ridoe on azimuths of $N$ $29 \mathrm{E}$ and $\mathrm{W} 32 \mathrm{~N}$ at distances of 2.7 miles $(4.4 \mathrm{~km})$ and 1 mile $(1.6 \mathrm{~km})$ respectively from the intersection of Bethel Valley Road and Melton Valley Access Road. The other two attes (Monongahola and Sequoia) are in Metton Valley on azimuths of E $30 \mathrm{~S}$ and $E 36 \mathrm{~S}$ at diatancse of $1.3 \mathrm{miles}(2.1 \mathrm{~km})$ and 1.4 miles $(2.2 \mathrm{~km})$ respectively from the intersection of Bethel Valloy Road and Melton Valloy Accoes Road.

General Dimensions and Capacties: Each of the four aites covers an aree of loas than $550 \mathrm{tt}^{2}\left(50 \mathrm{~m}^{2}\right)$.

Function of the Unit: The study was conducted on 12 white oak trees at 4 sites of contrasting soll types and moisture conditions. Throughout the growing season beaves were collected and analyzed for radionuclide distribution.

Dates of Operation: The trees were injected with Co-134 in Aprt of 1880. Two trees were double tagoed by injection with $K-42$.

Waste Characteristics: All trees in the study were injected with 2 mCl of Co-134 (half-fle 2.05 years), and two trees in each plot were also injected with $2 \mathrm{mCl}$ of $\mathrm{K}-42$ (half fife $12.4 \mathrm{~h}$ ). Total acthithy used was $24 \mathrm{mCl}$ of $\mathrm{Co}-134$ and $4 \mathrm{Cl}$ of $\mathrm{K}-42$.

Relase Data: If all of the original cesium inoculum remained in any single tree, less than $0.3 \mu \mathrm{Cl}$ of activity would remain. Because the trees were harvested at the end of the study, it was estimated that only $25 \%$ of the inoculum would remain. This would result in less than $0.1 \mu \mathrm{Cl}$ remaining at any tree site. Fladioactive decay has eliminated the $K-42$ (half-life $12.4 \mathrm{~h}$ ). 
EPA II.A.1 DATA SUMMARY SHEET

D Number: ER-13

Namo: Zn-65 Tagoed Red Oak

Seedilings

Location of Unit. Site ER-13 is located 1.6 miles $(2.5 \mathrm{~km})$ on an aximuth of $S 46 \mathrm{~W}$ trom the intersection of State Highway 95 and the Now Zlon Patrol Road. The site is sbout $680 \mathrm{Ht}(200 \mathrm{~m})$ north of Clinch River Mile 19.25.

General Dimensions and Capecitios: Approximately $1100 \mathrm{t}^{2}\left(100 \mathrm{~m}^{2}\right)$ of land was involved in this study.

Function of the Unit: Gamma-irradiated red oak seedinges were contaminated with Zn-65 to investigate the effects of lonizing radiation on zinc uptake. A total of 28 containers of seedinges were used.

Dates of Operation: The 12-week study period wes intiated in June 1975.

Waste Characteristics: A total of $1.3 \mathrm{mCl}$ of Zn-65 (half-fife $246 \mathrm{~d}$ ) was introctuced into the 28 seeding containers.

Relouse Data: Planted seedinges and all experimental materials were removed from the site when the study was completed. If the materials had been allowed to remain, lees than 1 pCl (total) of Zn-65 would exist at this site and would not be detectable. 
EPA II.A.1 DATA SUMMARY SHEET

1D Number: ER-14

Name: Co-134 Contaminated Pine and Oak Seedlings

Location of Unit: Site ER-14 is located in the 0800 ares a distance of 1.1 miles $(1.7 \mathrm{~km})$ on an azimuth of $S 18 \mathrm{~W}$ trom the intersection of State Highway 95 and the New Zlon Patrol Road.

General Dimensions and Cepacities: The total contaminated area is reported to be lese than $1100 \mathrm{Ht}^{2}$ $\left(100 \mathrm{~m}^{2}\right)$.

Function of the Unit: A number of short-term experiments conducted in the 0800 area were dealgned to determine initial interception and retention of fallout particles by various plant taxa.

Dates of Operation: In June 1988 white pine and red oak seedings were contaminated with Co-134 particles and sampling was carried out over a 33-d period.

Waste Characteristics: A total of $261 \mu \mathrm{Cl}$ of C.-134 partictes (half- lfte 2.05 years) was applied to 30 seedings ( $8.7 \mu \mathrm{Ci} /$ container).

Reloase Data: By the end of the study all experimental materials had been removed for sampling and analysis. There is a possibility that some contamination of the soil and orass at the stte may have occurred due to disfodged particles. Considering that nine half-lives have lapeed, lese that $1 \mu \mathrm{Cl}$ (total) would still be present if all of the radioactive material had been left in the field. 
EPA II.A.1 DATA SUMMARY SHEET

ID Number: ER-15

Name: Rb-88 Contaminated Plants

Location of Unit: Site ER-15 is located at the site of the pine-osk contamination study (ER-14) in the 0800 area. The site is a distance of 1.1 miles $(1.7 \mathrm{~km})$ on an azimuth of $\mathrm{S} 18 \mathrm{~W}$ from the intersection of State Highway 95 and the Now Zlon Patrol Road.

General Dimensions and Capacities: Two plots (33 tt by $33 \mathrm{ft}$ [ $10 \mathrm{~m}$ by $10 \mathrm{mD}$ were uttlized in this study.

Function of the Unit: This was another fallout-related study. Agrlouttural species were sprayed with partictes contaminated with Rib-88 to determine tractional interception and retention times of particles in two size classes.

Dates of Operation: The particles were applied to the plots in June 1869. The study was completed after seven woeks.

Waste Characteristics: A total of $12.48 \mathrm{mCl}$ of Rb-86 (halfitite $18.66 \mathrm{~d}$ ) was spplied to one plot, and the other plot received $19.8 \mathrm{mCl}$.

Release Data: Approximately 230 halftives have lapsed, and no detectable Rb-86 activity remains at the site. 
EPA II.A.1 DATA SUMMARY SHEET

ID Number: ER-16

Name: Co-134 Contaminated Soybean

and Sorghem

Location of Unit: Site ER-16 is located in the 0800 area 1.1 miles $(1.7 \mathrm{~km})$ on an azimuth of $S 18 \mathrm{~W}$ from the intersection of State Highway 95 and the Now Zlon Patrol Road.

General Dimensions and Capacities: The contaminated area utlized was about $2160 \mathrm{ft}^{2}\left(200 \mathrm{~m}^{2}\right)$.

Function of the Unit: This study was a continuation of research in plants and fallout effects. Twenty-five plants each of soybeans and sorghum were contaminated with Co-134. Particle slzes used in this study were lese than $10 \mu$ in diameter.

Dates of Operation: The site was contaminated in July 1970. The study lasted seven weeks.

Waste Characteristics: A total of $682 \mu \mathrm{Cl}$ of C. 134 (haffitte 2.05 years) was used in this study. Each week three plants of each species were removed for radiological determinations.

Release Data: The removal of the plants reduced the amount of radioactivity at the stre each week. At the end of the experiment all remaining experimental materials were removed. Considering that about eight hali-thes have now lapsed, only $3.0 \mu \mathrm{Cl}$ (total) would remain if all of the experimental materlals had been left at the site. 
EPA II.A.1 DATA SUMMARY SHEET

10 Number: ER-17

Name: C.134 Contaminated Graseces

Location of Unit: Stte ER-17 lo located in the 0800 area 1.1 miles $(1.7 \mathrm{~km})$ on an azimuth of $\mathrm{S} 18 \mathrm{~W}$ from the intersection of State Hotwway 98 and the New Zlon Patrol Road.

General Dimensions and Capactices: Four \&- by :33-tt (2.5- by 10-m) ploto totaling $1080 \mathrm{H}^{2}\left(100 \mathrm{~m}^{2}\right)$ were used in thile study.

Function of the Unit: The atudy was desioned to inveotloate the interception and retention of C.-134 contaminated partictes on torage and turt grasesse. Each of the four study plots contained different orases species.

Dates of Operation: Each of the four plots was contaminated in June 1970. The duration of the stucty was soven weoks.

Wasto Charactertstica: Each plot received perticles contaminated with $307 \mu \mathrm{Cl}$ of Co-134 (haifitte 2.06 years); a total of $1.23 \mathrm{mCl}$ of $\mathrm{Co}-134$ was utllized.

Redecese Data: The removal of plant materiale combined with radioective decay of the botope reduced

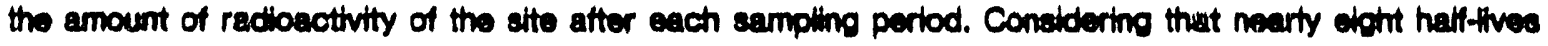
have lapeed since contamination, approximately $5.0 \mu \mathrm{Cl}$ (total) of Co-134 would remain if all of the expertmental materiala had remained at the site. Since all matertalo were removed, the remaining radioactivity should be negligiblo. 
EPA H.A.1 DATA SUMMARY BHEET

1D Number: ER-18

Name: Co-134 Contaminated Lhehens

and Moseses

Location of Untt: SHe ER. 18 is located in the 0800 area 1.1 miles $(1.7 \mathrm{~km})$ on an azimuth of $818 \mathrm{~W}$ from the intersection of State Hlighway 95 and the Now Zion Patrol Road.

General Dimenaions and Capactibs: One of the $33-$ by $33-1 t(10-$ by $10-\mathrm{m})$ plots used in previous fallout studies was used.

Function of the Unit: This was the final fallout study and examined lower plants' (Notiens and moeses) effects due to fallsut particulates. Cesium-134 was used as the contaminant.

Dates of Operation: In June 1971, the C.134 contaminated partictes were applied to indtuidual moses and lichen tuseocks (21 for each species).

Waste Charactertatics: Each contaminated point (155 $\mathrm{m}^{2}$ [1000 $\mathrm{cm}^{2} \mathrm{D}$ recatved $3.5 \mu \mathrm{Cl}$ of $00-134$ (half the 2.05 years); a total of $147 \mu \mathrm{Cl}$ was used in the study.

Reloase Data: All contaminated moss and lloton tussocks were removed for radiological examination during the study. All experimental materlals were also removed from the study area; however, If all of the radioactivity had been lett at the site, lese than $1 \mu \mathrm{Cl}$ (total) of $\mathrm{Co-134}$ would remain following radioactive decay. 
EPA II.A.1 DATA SUMMARY SHEET

D Number: ER-18
Namo: To-95m Contaminated Soll and Plants

Location of Unit: Site ER-19 is located in the 0800 area about $330 \mathrm{Ht}(100 \mathrm{~m})$ north of the weotern end of the fenced enclosure (SWMUU 13.1 in the RFA) north of the Clinch River at mith $20.5(\mathrm{~km} 33.2)$ on an azimuth south, 1.3 miles $(2.1 \mathrm{~km})$ trom the intersection of Bethel Valloy Road and State Highway 96.

General Dimensions and Capacitios: Approximately $3200 \mathrm{tt}^{2}\left(300 \mathrm{~m}^{2}\right.$ ) of land area was used in thits study. Twenty-two separate 10.8-1 $t^{2}\left(1-\mathrm{m}^{2}\right)$ plots were used during the study.

Function of the Unit: Used to evaluate the interception and retention of fiscion products by grasese and solts. The method of radiolsotope application differed from previous retention studise in that the nuctide was applied by llauld spray.

Dates of Operation: Three separate applications of Tc-96m occurred: 16 plots durng September 1978, 4 ploto during April 1979, and 3 plots during July 1979.

Waste Characteristics: The To-95m (halftfo $61 \mathrm{~d}$ ) was sprayed on the graes. In the first application, $200 \mu \mathrm{Cl}$ was applied to each of the 16 plots $(3 \mathrm{mCD})$; in the second application $10 \mu \mathrm{Cl}$ was appliod to each of the the four plots $(40 \mu \mathrm{CD})$; and in the finel application $10 \mu \mathrm{Cl}$ wes appiled to each of the three plots $(30 \mu \mathrm{CH})$. Total TC-95m applied was $3.07 \mathrm{mCl}$.

Rolease Data: Because of the short halfitte and the arnount of thme that has lapsed since application (8 years or more), radioective decay has recuced the concentration to levels that are not detectable at the site. 
EPA II.A.1 DATA SUMMARY SHEET

10 Number: ER-20

Name: To-95m Uptake Studies

Location of Unit: SHte ER-2O is located in the same general area as ER-19.

General Dimensions and Capscities: Three 10.8- $\mathrm{tt}^{2}\left(1-\mathrm{m}^{2}\right)$ plots were contaminated. Estimated area uttr tzed is $108 \mathrm{t}^{2}\left(10 \mathrm{~m}^{2}\right)$.

Function of the Unit: The uptake of the tectmettum by emerging plants in the field was compared with uptake in a companion greenhouse study in which soll columns were contaminated and emerging plants analyzed.

Dctes of Operation: The field portion of the stucty was pertormed in late Fobruary 1981.

Waste Characteristics: Each plot was contaminated with $112 \mu \mathrm{Cl}$ of TC-95m (hafftte 61 d) in solution (total $336 \mu \mathrm{CD}$ ).

Release Data: Approximately 31 half twes have lapeed ance initial field contamination. Conciderting the original microcurie quanttios and the radiological decay, the presence of the botope at the site is below detection. 
EPA II.A.1 DATA SUMMARY SHEET

D Number: EA21

Namo: Tc-95m and 1 131 Contaminated

Pasture

Location of Unit: Site EA21 is located in the same general ard as SWMU 13.1 in the RFA. The areas contaminated with To-95m and $1-131$ were isolated from the original Co-137 contaminated pens used in SWMUU 13.1.

General Dimensions and Cepecitios: The contaminated pesture area encompaseed 43,000 $\mathbb{H}^{2}$ (4000 $\left.\mathrm{m}^{2}\right)$.

Function of the Unit The purpose of the study wes to asseses the transter of the radibieotopee TC-95m and $1-131$ tom torage grass to milk in goats.

Dates of Operation: In May, Juty, and September of 1983 -131 was sprayed on the site. In September TC-95m wes atoo sprayed on the site.

Waste Characteristica: The total amount of $1-131$ (half the 8.05 d) applied was $80 \mathrm{mCl}$, and the Tc-96m (halffite 61 d) was $10 \mathrm{mCl}$.

Redease Data: Radioectivity of both isotopes is not dotectable because of radiological decay, the tectr nicium having gone through approximately 16 half tives and the iodine 128 halthives. 
EPA II.A.1 DATA SUMMARY SHEET

D Numbor: ER-22

Name: Cr-51 Contaminated Grass

Plots

Location of Unit: Site ER-22 is located in the 0800 area approximately $0.2 \mathrm{mil}(0.3 \mathrm{~km})$ on an azimuth of N 6 E of the northeast comer of the 0800 area enclosure.

General Dimensions and Capacities: Twenty-five $10.8-\mathrm{ft}^{2}\left(1 \mathrm{~m}^{2}\right)$ plots were expoeed.

Function of the Unit: The purpose of the study was to investigate the interception and retention of simulated cooling tower drift on vegetation (pine, yellow poplar, and fescue grase foliage).

Dates of Operation: Chromium-51 was applied to the grass plots in July 1976. Duration of the study was nine weeks.

Waste Characteristics: The plots were contaminated with an aerosol spray containing Cr-51 (half-ifte $27.8 \mathrm{~d})$. The 25 exposed plots received a total of $125 \mu \mathrm{Ci}$ of $\mathrm{Cr} .51$.

Release Data: Because Cr.51 has a short halffife and over 3600 days have passed since the plots mere contaminated, no detectable radioactivity remains at the site. 
EPA II.A.1 DATA SUMMARY SHEET

ID Number: ER-23

Name: To-99 and Np-237 Contaminated
Soll Lyaimoters

Location of Unit: Site ER-23 is located $0.3 \mathrm{mile}(0.5 \mathrm{~km})$ on an aximuth of $E 75.5$ from the intersection of Melton Valley Drive and Lagoon Road. The site is commonty reterred to as the phitonium floodplain, wivich is southeast of SWSA 4

General Dimensions and Capacitiea: The contaminated area was about $43.2 \mathrm{tt}^{2}\left(4 \mathrm{~m}^{2}\right)$.

Function of the Unit. Eght hysimeter cylinders $11 \mathrm{in.}(28 \mathrm{~cm})$ in diameter were contaminated with Np237 and four additional cylinders were comtaminated with Tc-99. The cylinders were covered on the bottom with meah such that dowmward migration of the racionuctide could occur. The cylinders were lowered into a hole such that the soil lovel in the cytinders was the same as that of the surrounding soll. Aoricuttural species were cultured in tho lyaimeters, harveeted, and anatyzed for concentration ratio calculatione.

Dates of Operation: The study was performed in June 1884.

Waste Characteristics: A total of $64 \mu \mathrm{Cl}$ of $\mathrm{Np}-237$ (halfffie $2.14 \times 10^{\circ}$ ) and $32 \mu \mathrm{Cl}$ of Tc-99 (halftife $\left.2.12 \times 10^{5}\right)$ was added to the 12 lysimeter cylinders.

Release Data: At the terminition of the study, all of the cytinders were removed from the soil and encased in plastic; they are presently in storage awaiting disposal. No radioactuity remains at the site. 
EPA II.A.1 DATA SUMMARY SHEET

1D Number: ER-24

Name: C8.137 Contaminated Forest

Floor

Location of Unit: Site ER-24 is located near ( $160 \mathrm{HI}[50 \mathrm{mD}$ the lower slope forest of Copper Ridge, a distance of 1.8 miles $(2.92 \mathrm{~km})$ on an azimuth of E $66 \mathrm{~S}$ from the imtersection of Bethel Valley Road and Metton Valley Access Rosd.

General Dimensions and Capactiles: A $16.5-$ by $16.5-\mathrm{Ht}(5-$ by $5-\mathrm{m})$ plot was contaninated with C8137. Estimated contaminated area is $270 . t^{2}\left(25 \mathrm{~m}^{2}\right)$.

Function of the Unit: The purpose of the study was to determine the transter of the cesium from the Hitter to successive soll depths following rainteacting and decay of the litter.

Dates of Operation: The firset floor wes contaminated by spraying with Ca-137 in April 1964.

Waste Characteristics: The exact amount of C8-13\% (half-fite 30 years) applied is not known; however, it is thought to have been in the order of $1 \mathrm{mCl}$ or less.

Releses Data: Since the initial contamination occurred, about 23 years have lapeed. If the intilial radioactivity was about $1 \mathrm{mCl}$, then about $0.6 \mathrm{mCl}$ would remain, subject to ditution by leaching and decay of the litter. 
EPA II.A.1 DATA SUMMARY SHEET

ID Number: ER-25

Namo: Co-137 Contaminated Foreat

Understory

Location of Unit: Site ER-25 is located about $33 \mathrm{Ht}(10 \mathrm{~m})$ west of the cesium foreet study enclosure (SWMU 16.1 in the RFA). The site is 1.8 miles $(2.92 \mathrm{~km})$ on an azimuth of $E 66 \mathrm{~S}$ from the intersection of Bethel Valley Road and the Melton Valley Access Road near the lower slope foreat of Copper Ridoe.

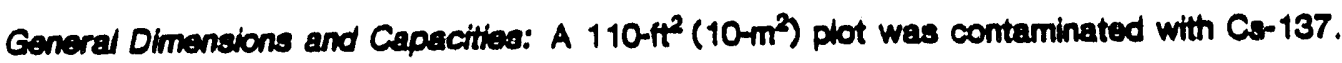

Function of the Unit: The study was desioned to determine the movement of radiocesium to litter and soil frorn the understory canopy.

Dates of Operation: The arse was sprayed with Co-137 on June 27, 1966.

Waste Characteristics: Plante, soll, and Btter were contaminated with $360 \mathrm{mCl}$ of Co-137 (haff-life 30 years).

Release Data: Twenty years have passud ( 0.67 half-lite) since the radionuctide was applied. The maximum residual radioactivity today would be about $220 \mathrm{mCl}$. Because of annual leaf-fall and wind dispersal, decomposition of the litter, runoff, and infiltration, it is unlikely that detectable levele remain. 


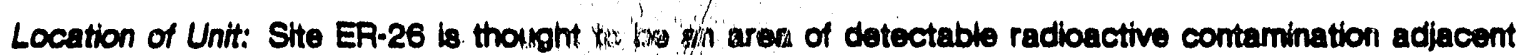
$(8.5 \mathrm{ft}[20 \mathrm{~m}]$ north) to the Co-137 rund thet (SWMUU 13.2 in the RFA). The exact position is not known.

General Dimensions and Capacities: An 8- by 8-ft (2.4- by 2.4-m) plot was contaminated with Co-137. Total area contaminated was $64 \mathrm{tt}^{2}\left(10 \mathrm{~m}^{2}\right)$.

Function of the Unit: This area served as a pilot study for the runoff soliterosion study (SWMU 13.2 in the RFA).

Dates of Operation: The exact date of botope application is not known but is thought to be in June 1964.

Waste Characteristics: $5 \mathrm{mCl}$ of C8-137 (halfitife 30 years) was applied in the form of a spray to clipped (short meadow) and unctipped (long meadow) grass cover within the plot.

Reloase Data: If the June 1964 date is correct, nearly 23 years (approximately 0.73 half-hte) have elapeed since the field was contaminated. If the onty lose of radioactivity were through radiological decay, approximately $3 \mathrm{mCl}$ would remain. Much less would actually be present duv to losess from rainout, plant fragmentation, and wind dispersal. 
EPA II.A.1 DATA SUMMARY SHEET

ID Number: ER-27

Name: Co.134 Contaminated Persimmon

Treo

Location of Unit: Stre ER-27 is located 0.3 mile $(0.4 \mathrm{~km})$ on an azimuth of E $73 \mathrm{~S}$ from the intersection of the Oak Ridoe Turnpike and Blair Road.

General Dimensions and Capacities: The contaminated area is estimated to be $65 \mathrm{ft}^{2}\left(6 \mathrm{~m}^{2}\right)$.

Function of the Unit: The study was designed to determire the transfer of the C8-134 radionuclide from a contaminated canopy to the understory by rainout.

Dates of Operation: In June 1970, a single persimmon tree was inoculated with Co-134. Duration of the study was approximatehy ten weoks.

Weste Characteristics: The tree was inoculated with approximately $2 \mathrm{mcl}$ of $\mathrm{Cs}-134$ (half 1 ife 2.05 years).

Revases Data: Nearty 18 years (or 9 haff-tives) have paseed since the radionuclide was introduced at the site. The maximum possible contaminant remaining would be approximately $8 \mu \mathrm{Cl}$. providing there were no losses from the site by rain (runoff or leaching), wind, or animal consumption. 
EPA H.A.1 DATA SUMMARY SHEET

DD Number: ER-28

Name: Co-60 and Min-54 Animal Study

Location of Unit: Site ER-28 is located 0.52 mile $(0.8 \mathrm{~km})$ on an azimuth of $\mathrm{S} 40 \mathrm{~W}$ from the intersection of the Oak Ridge Tumplke and the North Perimeter Patrol Road (ORGDP).

General Dimensions and Capacties: The atte was a 2.5-acre (1 ha) field.

Function of the Unt: The purpose of the experiment was to determine the effects of neartethal trradiation and natural environmental factors on the retention and excretion of the two muctides used fCo-60 and Mn-54) in members of a field population.

Dates of Operation: In July 1970, 34 pine voles were gamma-mradiated; of theee, 17 more iniected with Co-60 and the other 17 were injected with Mir-54 and released to the field.

Waste Characteristics: The animals were hiected with a total of $17 \mu \mathrm{Cl}$ of Coso (half the 5.2 yeara) and $17 \mu \mathrm{Cl}$ of $\mathrm{Mn}-54$ (halt tife 0.82 year8).

Release Data: Considering that over three haffitives have lapsed in the decay of the Co-60 contaminant, approximately $2.6 \mu \mathrm{Cl}$ of this botope would remain today provided that all 17 animals remained within the 2.5-acre field. In the case of the Mn-54, radiological decay would have reduced the remaining amount to less than $16 \mathrm{pCl}$. The amounts of radioactivity present at the site are expected to be much less than these values and thus would be undetectable. 
EPA Il.A.1 DATA SUMMARY SHEET

D Number: ER-29

Nama: C-14 Maintenanco-Peapiration Study

Location of Unit: Site ER-29 is located 1.7 miles $(2.75 \mathrm{~km})$ on an azimuth of N 22 E from the intersection of Bear Croek Road and Gum Branch Road. Site is on the north side of Pine Ridoe.

Genergl Dimensions and Capacities: The area involved in the study was $2150 \mathrm{t}^{2}\left(200 \mathrm{~m}^{2}\right)$.

Function of the Unit: Thirty-six trees were contaminated with C-14 to study the movement of carbon during respiration. The lsotope was introduced as carbon dioxide.

Dates of Operation: Twenty trees were contaminated with the C-14 in June 1983, and another 18 trees in June 1884.

Waste Characteristics: The first group of 20 trees were contaminated by follar tagging with a total of approximately $1 \mathrm{mCl}$ of $\mathrm{C}-14$, and the second group with $2 \mathrm{mCl}$. The hatiftie of $\mathrm{C}-14 \mathrm{ls} 5479$ years.

Release Data: Research data demonstrated that exposed follage abeorbed $\geqslant 2 \%$ of the contaminant (C-14) gas. It was also noted that most of the radiocarbon was released within the first week of samping foliage. Experimental protocol identfied C-14 labeled branches with tags. All tagged branchoa were removed upon completion of the study. Due to low levels of exposure, no detectable radiation would be present at the site today. Radiocarbon has a long halitife, but because of the woak beta energy (0.156 MoV) it does not constitute an exposure hazard. As the plant material decomposed, a portion of the radiocarbon was dispersed into the atmosphere as carbon dioxide. 


\section{EPA II.A.1 DATA SUMMARY SHEET}

1D Number: EA-30

Name: C-14 Sucrose Inoculation of

Oak and Pines Trees

Location of Unit: Site ER-30 is located near the Co-134 contaminated foreet (SWMU 16.1 in the RFA). It is 1.8 miles $(2.9 \mathrm{~km})$ on an azimuth of E $66 \mathrm{~S}$ trom the intersection of Bethel Valloy Road and Melton Valley Access Road.

General Dimensions and Capactios: The area of contamination is reported to be $1100 \mathrm{Ht}^{2}\left(100 \mathrm{~m}^{2}\right)$.

Function of the Unit: Two studies were conducted. Both were designed to determine the spatial und temporal pattern of carbohydrate movement and respiratory use by the root systems of trees.

Dates of Operation: in October 1972, three trees were moculated with G-14 sucroes, and in October 1876 a single white oak tree was inoculated with C.14 sucroes.

Waste Cheractertatics: Each of the three treee received $1.85 \mathrm{mCl}$ of $\mathrm{C}-14$ (halfthe 5479 years), and the fourth tree received $5 \mathrm{mCl}$ (total of $8.85 \mathrm{mCn}$.

Release Data: Study protocol required tagging of labeled branches and all tagoed branches were subsequently removed upon study completion. Radiocarbon has a long half-the, but because of the weak beta energy $(0.156 \mathrm{MeV})$ it does not constitute an exposure hazard. As the plant material decomposed, a portion of the radiocarbon was dispersed into the atmosphere as carbon dioxide. 
EPA II.A.1 DATA SUMMARY SHEET

ID Number: ER-31

Namo: C-14 Allocation in Whito Oak Trees

Location of Unit: Sthe ER-31 lo located a diatance of 1.9 miles $(3.1 \mathrm{~km})$ on an aztmuth of N 25 E from the intereection of Bethel Valloy Road and Melton Valloy Access Road.

General Dimenaions and Capactiles: The area of contamination is reported to be $2150 \mathrm{tt}^{2}\left(200 \mathrm{~m}^{2}\right)$.

Function of the Unit: Two studies were conducted in this area. The purpose of the first was to determine scasonal changes in photoeynthate translocation and allocation by following the rates of movernent of the C-14 from labeled follage, and the second was to follow the rate and efficienoy of the uttilzation of tood reserves.

Dates of Operation: The studies were conducted between 1972 and 1977.

Wasto Characteristica: in the first study, two trees were contaminated by follar tagoing uaing C-14. Each of the two trees received $50 \mu \mathrm{Cl}$. In the second study, two treese received thoculations of $5 \mu \mathrm{Cl}$ of C-14 sucrose. The halftife of $\mathrm{C}-14$ is 5479 years.

Release Data: Upon completion of the study, tagged trees were removed. One large oak remained; however, all tagoed branches were removed from the oak tres. Radibcarbon has a long halfiffe, but be use of the weak beta energy $(0.158 \mathrm{MoV})$ it does not conottute an exposure hazard. As the plant $m$ isrial decomposed, a portion o wi radiocarbon was dispersed into the atmosphere as carbon dioxbat. 
EPA II.A.1 DATA SUMMARY BHEET

ID Number: ER-32

Namo: C-14 Allocation in White Pine

Treos

Location of Unit: SHte ER-32 is located a distance of 1.8 miles $(2.9 \mathrm{~km})$ on an aztmuth of N S5E from the intersection of Bethel Valley Road and the Metton Valley Access Road. It is Identtfied by a pine stand south of Bethel Valley Road noar the Walker Branch Embayment of Melton Hill Lake.

Ceneral Dimensions and Capactiles: The area of contamination to reported to be 1.25 acres $(0.6 \mathrm{ha})$.

Function of the Unit: The purpose of the study was to determine the rate and cause of dectining vioor of oxidant-stressed trees by following the rate of photosynthetically fixed C-14.

Dates of Operation: Between June and November 1979, nime white pine trees were labeled by follar tagoing with C.14.

Weste Charactertstics: A total of $380 \mu \mathrm{Cl}$ of $\mathrm{C}-14$ (half-hite 5479 years) was introduced to follage at four times during the growing season.

Release Data: Study protocol required tagoing of lebeled brancties. At the end of the study all tagoed branches were curt. Any resitual C-14 was diluted th the blomass and, therefore, could not be detected. (At a later date, a number of these trees were removed with the construction of a power ine.) Radiocarbon has a long haliflite, but because of the weak beta energy $(0.156 \mathrm{MeV})$ it does not consth tute an exposure hazard. As the plant material decomposed, a portion of the radiocarton was dispersed into the atmosphere as carbon dioxide. 
EPA II.A.1 DATA SUMMARY SHEET

1D Number: ER-33

Neme: C14 Efflux in Yellow Poplar

stand

Location of Unit: SHto ER-33 lo located a dietance of 1.8 miles $(2.9 \mathrm{~km})$ on an azimuth of $E 76 \mathrm{~S}$ from the intersection of Bethel Valley Roed and Melton Valloy Acceses Road. Site is on the north slope of Copper Riloo.

General Dimensions and Capactilies: The area of contamination is reported to be $2180 \mathrm{tt}^{2}\left(200 \mathrm{~m}^{2}\right)$.

Function of the Unit: The purpose of the study was to measure carbon dioxide efflux of the roots through the soll. Following introduction of the C-14 to three trees, the trees were girdled to inhibit upwerd transiboation.

Dates of Operation: The three yellow poplar trees were contaminated in Juty 1976.

Wasto Characteristics: A total of $3 \mathrm{mCl}$ was inoculated into the trees as C-14 sucrose (halfifte 5479 years).

Release Data: Stems were givelled to intiblt upward transiocation of the raclocarbon. At the end of the study, roots, trees, and/or labeled branches were removed. Radiocarbon has a long half-life, but beceuse of the weak beta energy $(0.158 \mathrm{MoV})$ H does not constitute an exposure hazard. As the plant matertal decomposed, a portion of the radiocarton was dispersed into the atmosphere as carbon dioxido. 
EPA N.A.1 DATA SUMMARY SHEET

ID Number: ER-34

Name: C-14 Allooation in Woody

Blomases Plantation Spccios

Location of Unit: SHte ER-34 is located at the OANL site in the Woody Blomass Plantation south of Bullding 1503.

General Dimensions and Capactiles: The area of contamination ts reported to be 1.25 acres (0.5 ha).

Function of the Untt: The purpose of the study was to determine photosynthate allocation. Several species of trees in the Woody Blomass Plantation were included in the study.

Dates of Operation: The C-14 was introduced as a gas to tollage contained in exposure curvettes.

Waste Characteristics: A total of $1 \mathrm{nCl}$ of $\mathrm{C}-14$ carbon cloxide was used in the study.

Release Data: Study protocol required tagaing of labeled branchios and all tagped branchee were aubsequently removed upon study completion. Radiocarbon has a long half the, but because of the weak beta energy $(0.156 \mathrm{MoV})$ it does not constitute an exposure hazard. Following this study, all plant material was removed and disposed. No contamination should remain at the site. 
LIST OF PRJPARERS

$\begin{array}{ll}\text { C. E Nix } & \text { EC \& HP } \\ \text { Ann Geisler } & \text { EC \& HP } \\ \text { J. T. Kitchings III } & \text { EC \& HP } \\ \text { W. J. Boegly, Jr. } & \text { ESD } \\ \text { D. D. Huff } & \text { ESD } \\ \text { J. R. Trabalka } & \text { ESD } \\ \text { R. H. Ketelle } & \text { ED } \\ \text { T. E Myrick } & \text { OP }\end{array}$

RMPORT PRIPARATION

$\begin{array}{ll}\text { C. M. Selvula } & \text { Editor } \\ \text { J. S. Cox } & \text { ESD } \\ \text { D. G. Cottrell } & \text { Graphics } \\ \text { Graphics Dept. } & \text { ESD }\end{array}$

EC \& HP - Environmental Compliance \& Health Protection

ED - Energy Division

ESD - Environmental Sciences Division

OP $\quad$ - Operations Division 
ORNL/RAP12/V3

\section{INTERNAL DISTRIBUTION}

1. J. S. Baldwin

2. J. B. Berry

3-4. W. J. Boegly

5. T. A. Bowers

6. T. W. Burwinkle

7. J. B. Cannon

8. W. W. Chance

9. K. E Cook

10. N. H. Cutshall

11. P. E. Hollenbeck

12. F. J. Homan

13-14. D. D. Huff

15. R. H. Ketelle

16-17. L. W. Long

18. L. L. MeCauley

19. L. E MeNeese

20. L. J. Mezga

21. M. E Mitchell

22. F. R. Mynatt

23-38. T. E Myrick

39. C. E. Nix

40. R. E. Norman
41-55. P. T. Owen

56. D. C. Parzyck

57. T. A. Perry

58. D. E. Reichle

59. P. S. Rohwer

60. T. H. Row

61. C. M. Selula

62. F. E. Sharples

63. B. P. Spalding

64. S. H. Stow

65-66. L. E. Stratton

67. J. H. Swanks

68. T. O. Tallant

69. J. R. Trabalika

70. L. D. Voorhees

71. R. S. Wiltshire

72. Laboratory Records Depar: zent-RC

73-74. Laboratory Records Department

75. Central Research Library

76. Y-12 Technical Library

77. ORNL Patent Section

\section{EXTERNAL DISTRIBUTION}

78. Assistant Manager, Energy Research and Development, DOE/ORO, P.O. Box E, Oak Ridge, TN 37831

79-80. Office of Scientific and Technical Information, P.O. Box 62, Oak Ridge, TN 37831 

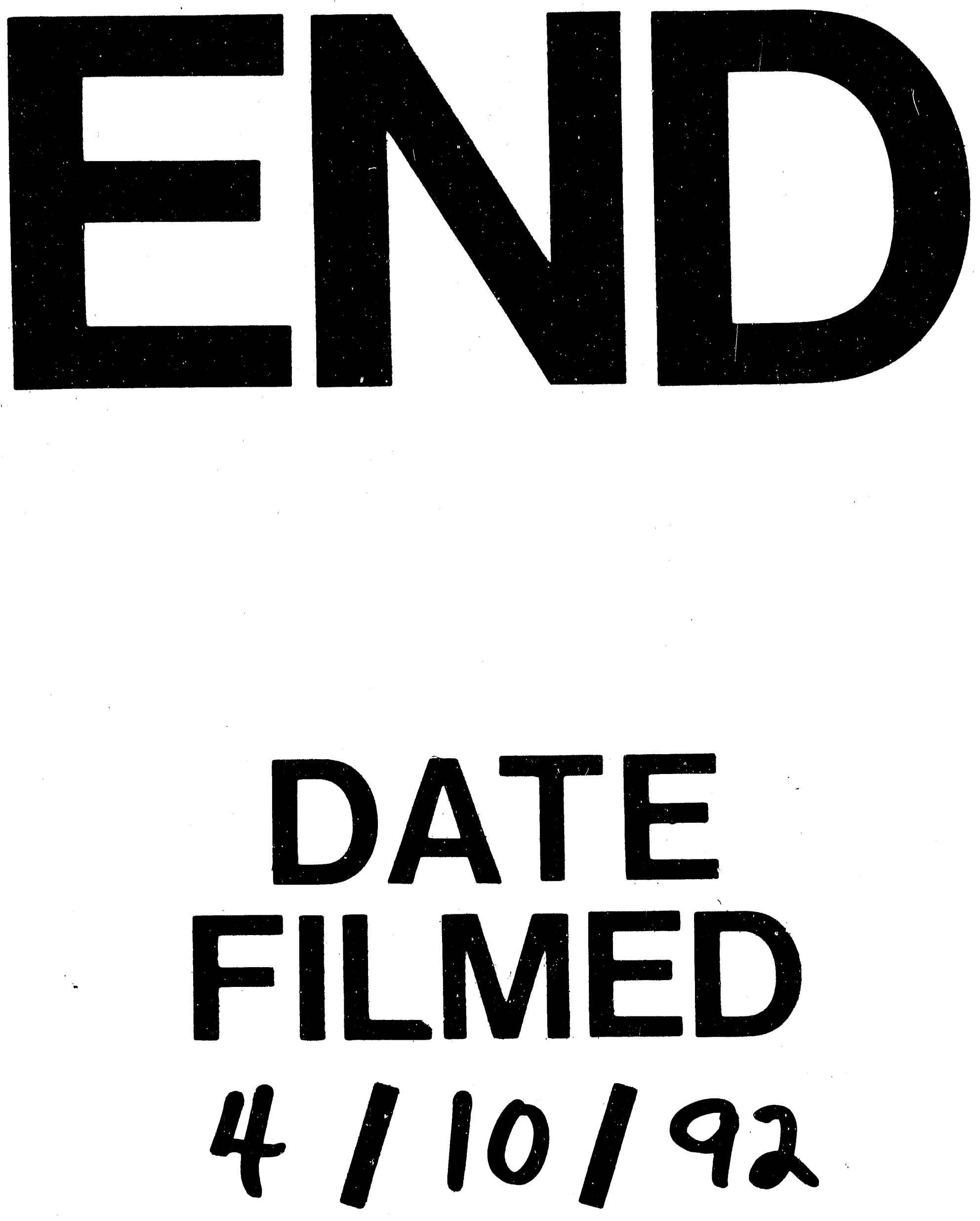
